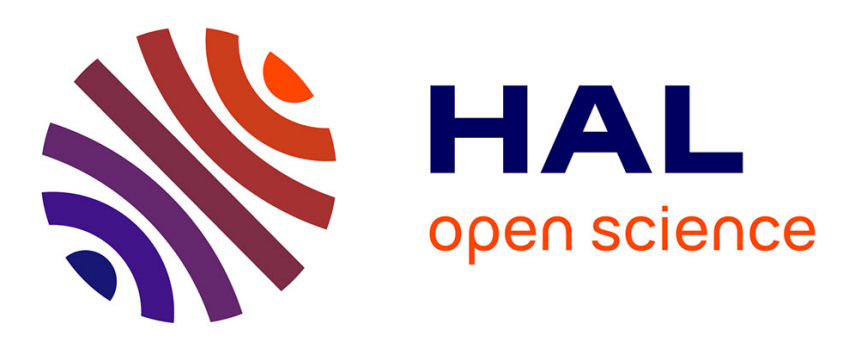

\title{
Sex-dependent compensated oxidative stress in the mouse liver upon deletion of catechol O-methyltransferase
}

Jofre Tenorio-Laranga, Pekka T. Männistö, Maria Karayiorgou, Joseph A. Gogos, J. Arturo García-Horsman

\section{To cite this version:}

Jofre Tenorio-Laranga, Pekka T. Männistö, Maria Karayiorgou, Joseph A. Gogos, J. Arturo GarcíaHorsman. Sex-dependent compensated oxidative stress in the mouse liver upon deletion of catechol O-methyltransferase. Biochemical Pharmacology, 2009, 77 (9), pp.1541. 10.1016/j.bcp.2009.02.004 . hal-00493491

\section{HAL Id: hal-00493491 https://hal.science/hal-00493491}

Submitted on 19 Jun 2010

HAL is a multi-disciplinary open access archive for the deposit and dissemination of scientific research documents, whether they are published or not. The documents may come from teaching and research institutions in France or abroad, or from public or private research centers.
L'archive ouverte pluridisciplinaire HAL, est destinée au dépôt et à la diffusion de documents scientifiques de niveau recherche, publiés ou non, émanant des établissements d'enseignement et de recherche français ou étrangers, des laboratoires publics ou privés. 


\section{Accepted Manuscript}

Title: Sex-dependent compensated oxidative stress in the mouse liver upon deletion of catechol O-methyltransferase

Authors: Jofre Tenorio-Laranga, Pekka T. Männistö, Maria Karayiorgou, Joseph A. Gogos, J. Arturo García-Horsman

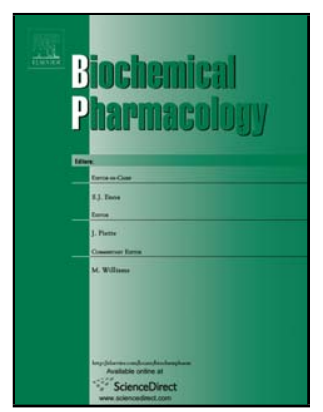

PII:

S0006-2952(09)00106-3

DOI: doi:10.1016/j.bcp.2009.02.004

Reference: BCP 10085

To appear in: $\quad B C P$

Received date: $\quad 15-12-2008$

Revised date: $\quad$ 9-2-2009

Accepted date: $\quad$ 11-2-2009

Please cite this article as: Tenorio-Laranga J, Männistö PT, Karayiorgou M, Gogos JA, García-Horsman JA, Sex-dependent compensated oxidative stress in the mouse liver upon deletion of catechol O-methyltransferase, Biochemical Pharmacology (2008), doi:10.1016/j.bcp.2009.02.004

This is a PDF file of an unedited manuscript that has been accepted for publication. As a service to our customers we are providing this early version of the manuscript. The manuscript will undergo copyediting, typesetting, and review of the resulting proof before it is published in its final form. Please note that during the production process errors may be discovered which could affect the content, and all legal disclaimers that apply to the journal pertain. 
The changes on the proteome of mouse liver, upon deletion of catechol $\mathrm{O}$-methyl transferase, are sex-dependent and were found in metabolic, regulatory and structural proteins.

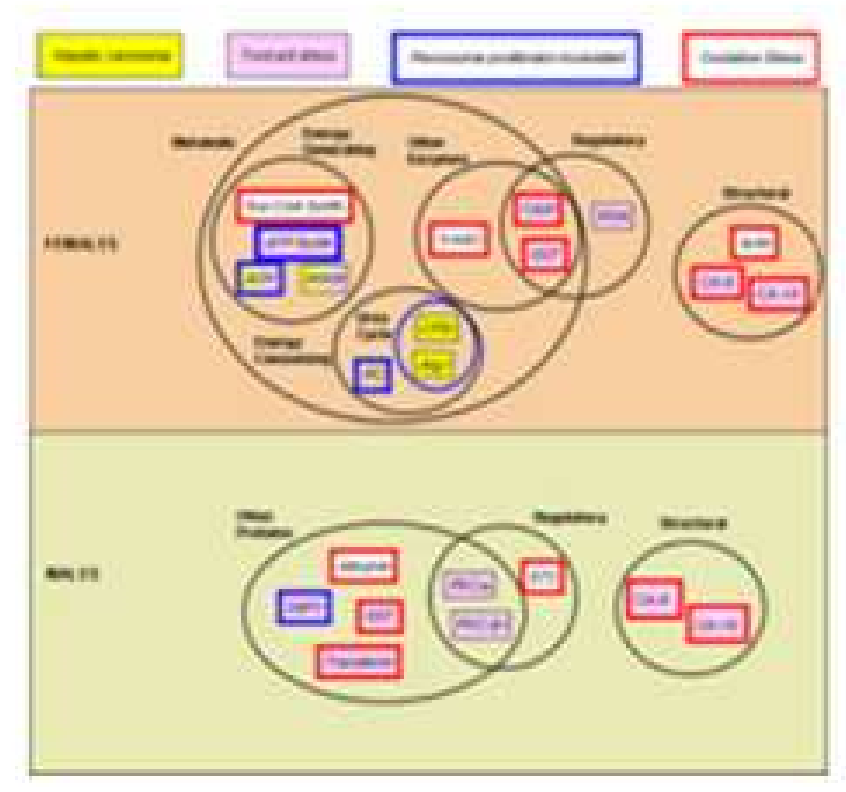




\title{
Sex-dependent compensated oxidative stress in the mouse liver upon deletion of catechol O-methyltransferase
}

\author{
Jofre Tenorio-Laranga ${ }^{1,2}$, Pekka T. Männistö ${ }^{1}$, Maria Karayiorgou ${ }^{3}$, Joseph A. \\ Gogos ${ }^{4}$ and J. Arturo García-Horsman ${ }^{1,2, *}$
}

\author{
${ }^{1}$ Division of Pharmacology and Toxicology, University of Helsinki, Finland, \\ ${ }^{2}$ Centro de Investigación Príncipe Felipe, Valencia, Spain, ${ }^{3}$ Department of \\ Psychiatry, Columbia University, New York 10032, USA, ${ }^{4}$ Department of \\ Neuroscience and Department of Physiology and Cellular Biophysics, Columbia \\ University, New York, NY, 10032, USA.
}

* Corresponding author: J. Arturo García-Horsman, Division of Pharmacology and Toxicology, University of Helsinki, P.O. Box 56 (Viikinkaari 5E), 00014 Finland. URL: http://www.helsinki.fi/farmasia/farmakologia/english/mainpage.htm Tel.+358 9191 59459; Fax.+358 9191 59471; E-mail: arturo.garcia@helsinki.fi

Running title: COMT knockout proteome

Abbreviations: ADH, aldehyde dehydrogenase; ATP synth, ATP synthase, AldoB, fructose 1,6-diphosphate aldolase B; Arg I, arginase I; CAIII, carbonic anhydrase 3; CHAPS, 3-[(3-Cholamidopropyl)dimethylammonium]-1-propanesulfonate; COMT, catechol O-methyl transferase; COMT-KO, catechol $O$-methyl transferase knock-out; CK-18, cytokeratin-18; CK-8, cytokeratin-8; CPSI, carbamoyl-phosphate synthase I; DIGE, differential gel electrophoresis; DOPAC, 3,4-dihydroxy-phenylacetic acid; DTNB, 5,5'-dithiobis-2-nitrobenzoic acid; EF2, elongation factor-2; GST, glutathiones-transferase; HVA, homovanillic acid; PC, pyruvate carboxylase; PKC, protein kinase $\mathrm{C}$; RGN, Regucalcin; ROS, reactive oxygen species; SBP2, selenium binding protein2; Suc-CoA Synth., Succinyl-CoA synthase; TBA, thiobarbutiric acid; TCA, trichloroacetic acid; TNB, 5-thio-2-nitrobenzoic.

Classification: Pulmonary, Renal and Hepatic Pharmacology

Enzymes: Catechol O-methyl transferase EC 2.1.1.6

Keywords: COMT, oxidative stress, dopamine, Parkinson's disease, proteomics

Subdivision: Gene expression. 


\section{Summary}

Catechol-O-methyl transferase (COMT) methylates catechols, such as L-dopa and dopamine, and COMT deficient mice show dramatic shifts in the metabolite levels of catechols. Increase in catechol metabolite levels can, in principle, lead to oxidative stress but no indices of oxidative stress have been reported in COMT-knockout (KO) mice [1]. Here we perform a proteomic based analysis of the livers of COMT-KO mice in search for potential compensatory mechanisms developed to cope with the effects of disrupted catechol metabolism. We found sex specific changes in proteins connected to stress response. Our results show that alterations in protein levels contribute to the homeostatic regulation in the liver of COMT deficient mice. 


\section{Introduction}

Catechol-O-methyltransferase [COMT; EC 2.1.1.6] catalyses the transfer of the methyl group of S-adenosyl-L-methionine into one of the phenolic groups of the catechol substrate in the presence of $\mathrm{Mg}^{2+}$. COMT is found in most mammalian tissues, with highest activity in the liver [2]. Females have lower COMT activities than males, at least in part due to estrogen down regulation of the promoter function [3, 4].

COMT deficient mice line has been used to evaluate the importance of COMT in catecholamine metabolism. In this animal model, there are dramatic changes in dopamine metabolism; the levels of 3,4-dihydroxyphenylacetic acid (DOPAC) are increased several fold while homovanillic acid (HVA) is undetectable [5-7]. In spite of that, tissue and extracellular dopamine levels have generally not been increased with the exception of the prefrontal cortex a modest increase of dopamine level (20-25\%) was seen in male mice [5]. More importantly, a 2-fold slower decay of dopamine has been observed in the frontal cortex but not in the striatum [8]. Also, in young hairless puppies the skin tyrosinase activity was increased in the mice lacking COMT [1].

COMT deficiency results in a number of behavioural deficits, often in a sexually dimorphic and gene dosage dependent manner. COMT-deficient mice show an increase of aggressive behaviour and altered response in anxiety tests [5]; altered d-amphetamine induced locomotion induction [9] altered exploratory phenotypes [10] as well as a number of cognitive deficits $[11,12]$. Additional phenotypes have also been described, such as blunted hypertensive response to sodium loading [13], enhanced voluntary ethanol drinking [14] and altered pain perception [15].

COMT inhibitors are being used as adjuncts to L-dopa decarboxylase inhibitor therapy in Parkinson's disease (PD). It has been suggested that L-dopa and dopamine are toxic to dopaminergic cells, and therefore the dopamine substitution therapy would 
enhance oxidative stress in PD patients and in this way accelerate the progression of the disease $[16,17]$. Several in vitro results indicate that, at high micromolar concentrations, L-dopa and dopamine are indeed toxic to dopaminergic cells and this effect can be linked to increased formation of ROS [18-20]. However, the in vivo evidence of any neuronal damage of L-dopa is conflicting and even a cell protecting role has been reported (reviewed in [16]).

Normally, the toxicity of ROS can be handled by defence mechanisms that are readily induced in vivo (see [21]). For example, the following pathways are activated: a) degradation of $\mathrm{H}_{2} \mathrm{O}_{2}$ by catalase and glutathione peroxidase; b) synthesis of reduced glutathione (GSH) by $\gamma$-glutamylcysteine synthetase and reduction of oxidized glutathione (GSSG) by glutathione reductase; c) the activity of glutathione transferase and quinone reductase. Simultaneously, some endogenous ROS-generating systems, like liver cytochrome P450 mono-oxygenases, may be repressed. There is evidence from post-mortem studies that GSH levels are decreased [22-24] and iron levels increased in the substantia nigra in $\operatorname{PD}[22,25,26]$. However, the activities of $\gamma$ glutamylcysteine synthetase, glutathione peroxidase and glutathione transferase were not changed [27]. A GSH deficiency may decrease the capacity of brain tissue to reduce $\mathrm{H}_{2} \mathrm{O}_{2}$ and an increased reactive iron may promote the formation of potentially cytotoxic $\cdot \mathrm{OH}$ radical from $\mathrm{H}_{2} \mathrm{O}_{2}[16,28,29]$.

L-dopa, endogenous catecholamines and their hydroxylated metabolites are all substrates of COMT (see $[2,30])$ and the reaction products (3-O-methyldopa, 3methoxytyramine and homovanillic acid) may be less susceptible to auto-oxidation and even have some antioxidative properties $[31,32]$. Since second-generation COMT inhibitors are being used as adjuncts to L-dopa decarboxylase inhibitor therapy in PD, it is important to determine whether deficient COMT activity would modify oxidative 
stress in the brain, but also in the peripheral tissues. To our knowledge, there are only two conflicting reports dealing with this issue $[33,34]$. In our previous studies on COMT deficient mouse liver, only mild changes were seen in glutathione S-transferase and quinone reductase [1], which were not robust enough to indicate the presence of oxidative stress in these animals. Our preliminary proteomic studies had indicated that glutathione related enzymes and protein kinase $\mathrm{C}$ were dysregulated in a sex-dependent manner [35]. We have now performed a comprehensive proteomic analysis of the liver from COMT-deficient mouse, in search of compensatory mechanisms developed to deal with dramatic changes on dopamine-related metabolite levels and a potential increase of a number of environmental COMT substrates (e.g. dietary polyphenols), some of which may be harmful. Also, activities of enzymes related to oxidative stress were measured in order to determine stress and stress defence indices in the livers of COMT-deficient mice.

\section{Materials and methods.}

\subsection{Animals}

Comt gene disrupted mouse strain was originally generated by Gogos and co-workers [5], the mutated COMT allele was originally introduced to mixed 129Sv/C57Bl/6J genetic background and by six generation backcrossing the mutation was introduced into a more homogeneous $\mathrm{C} 57 \mathrm{Bl} / 6 \mathrm{~J}$ genetic background. To collect homozygous mice and their wild type littermates, heterozygous males and females were bred. Comt gene disrupted homozygous (COMT(-/-)) mice as well as their wild-type littermates, were six to eight months old at the time the samples were taken. The procedures with animals 
were performed according to European Community Guidelines for the use of experimental animals and reviewed by the Animal Ethics Committees at the University of Helsinki in conformance with current legislation.

\subsection{Genotyping}

Genomic DNA was isolated from tail biopsies as described in [36]. For genotyping, a PCR method was developed using 5'-ACCATGGAGATTAACCCTGACTACG-3' (sense), 5'-GTGTGTCTGGAAGGTA GCGGTC-3' (antisense) primer set to detect COMT gene (comt) alleles, and 5'-GTGTTCCGGCTGTCAGCGCA-3' (sense), 5'GTCCTGATAGC-GGTCCGCCA-3' (antisense) primer set to detect mutant alleles containing the neomycin gene (neo) cassette that replaces the exons 2-4 of the COMT gene. Genomic PCR was completed using the Fail Safe PCR system (Epicentre Technologies, Madison, WI, USA) using Fail Safe buffer B and the following thermal cycles: an initial denaturing at $98^{\circ} \mathrm{C}$ for 1 min and 35 cycles consisting of denaturing temperature of $94^{\circ} \mathrm{C}$ for $30 \mathrm{~s}$, annealing temperature of $65^{\circ} \mathrm{C}$ for $1 \mathrm{~min}$, and extension at $72^{\circ} \mathrm{C}$ for $3 \mathrm{~min}$ with a final extension of $70^{\circ} \mathrm{C}$ for $10 \mathrm{~min}$. The amplified fragments were visualized by ethidium bromide staining under UV light after electrophoresis in a $1.7 \%$ agarose gel.

\subsection{Two-dimensional difference gel electrophoresis (2D-DIGE)}

For proteomics analysis tissues were homogenised with $7 \mathrm{M}$ urea, $4 \mathrm{M}$ thiourea and 4\% CHAPS (GE Healthcare, Uppsala, Sweden) with a ratio of $3 \mathrm{ml}$ per mg of tissue. After homogenisation samples were spun at $100,000 \mathrm{xg}$ for $30 \mathrm{~min}$, and the supernatant was 
kept. The 2-D DIGE experiments were carried out by the proteomics facility of the Centro de Investigación Príncipe Felipe, Valencia, Spain. Each gel was loaded with a mixture of differentially labelled protein from wild type and COMT KO livers. Duplicates of a total number of 4 gels per gender were run using samples from 4 different COMT KO and 4 different wild type animals. Samples were differentially labelled with the fluorescent dyes Cy2, Cy3, or Cy5 (GE Healthcare, Piscataway, USA). The protein standard, labelled with Cy2, consisted of a protein-pool of all homogenates used in the analysis at the same proportions. This Cy2-labelled protein-standard and the Cy3, or Cy5, labelled liver homogenate from wild type, or COMT KO, were combined for IEF and SDS-PAGE. The differentially labelled 2D-gels were serially imaged by laser scanning using Typhoon 9400 (GE Healthcare, Piscataway, USA). Images were normalized against the protein standard and quantitatively analysed using DeCyder software (GE Healthcare Piscataway, USA). Spots which showed statistically relevant density changes were localized in gels, cut out, reduced, alkylated, trypsinized and analysed by LC-MS/MS, using Qstar XL instrument (Applied Biosystems, Foster City, USA). The peptides resulted from digestion were applied in a reverse phase HPLC PepMap C-18 (75 $\mu \mathrm{m}$ x $150 \mathrm{~mm}$, LC-Packing) at $200 \mathrm{nl} / \mathrm{min}$ flow, and separated by a $14-47 \%$ acetonitrile gradient in $0.1 \%$ formic acid. Eluted fractions were directly applied to a nanospray source of the mass spectrometer, and IDA (informationdependent acquisition) analysis was carried out with acquisition cycles in MS and MS/MS mode along all the chromatogram. Resulting MS/MS spectra were sent to MASCOT server (www.matrixscience.com) using Mascot Daemon programme (Matrix Science Ltd London, UK).

\subsection{Phospho-protein detection in 2D-PAGE}


Phosphoproteins detection experiments were carried out by the proteomics facility of Centro de Investigación Principe Felipe, Valencia, Spain. Liver homogenate from wild type mice were separated by IEF and SDS-PAGE. The 2D-PAGE were stained for total protein detection with Sypro Ruby (Molecular Probe, Leiden, the Netherlands ) and with Pro-Q Diamond (Molecular Probe, Leiden, the Netherlands ) for detection of phosphate groups attached to tyrosine, serine or threonine residues. 2D-gels were imaged by laser scanning using Typhoon 9400 (GE Healthcare, Uppsala, Sweden).

\subsection{Tissue preparation}

Liver was homogenized in $1 \mathrm{ml}$ of buffer (sucrose $250 \mathrm{mM}, 10 \mathrm{mM}$ Tris-HCl pH 7.4 and PMSF $0.1 \mathrm{mM}$ ) per $100 \mathrm{mg}$ of tissue with a Teflon homogenizer (5 strokes) and centrifuged at $1000 \mathrm{x} \mathrm{g}$ for $10 \mathrm{~min}$.

\subsection{Glutathione determination}

Total glutathione was determined by the increase of absorbance at $405 \mathrm{~nm}$ due to 5-thio2-nitrobenzoic (TNB) formation in presence of glutathione reductase and 5,5'-dithiobis2-nitrobenzoic acid (DTNB), using glutathione assay kit (Cayman chemical, Ann Arbor, USA) following manufacturer's instructions. To determinate the oxidized glutathione, the same kit was used but derivatizing reduced glutathione was blocked with 2vinylpyridine before the assay.

\subsection{Glutathione peroxidase}


Glutathione peroxidase activity was determined by measuring the variation of absorbance at $340 \mathrm{~nm}$ in presence of NADPH, glutathione, glutathione reductase and ter-butyl hydroperoxide, using BIOXYTECH GPx-340 kit (Oxiresearch, Foster city, USA).

\subsection{Glutathione reductase}

Glutathione reductase activity was determined by measuring the variation of absorbance at $340 \mathrm{~nm}$ in presence of GSSG and NADPH, as described in the glutathione reductase assay kit (TREVIGEN Gaithersburg, USA).

\subsection{Lipid peroxidase}

To measure the lipid peroxidase activity, $50 \mu$ of liver tissue samples were diluted to $500 \mu$ with $250 \mathrm{mM}$ sucrose, $10 \mathrm{mM}$ Tris- $\mathrm{HCl} \mathrm{pH} 7.4$ and incubated at $37^{\circ} \mathrm{C}$ for 2 hours. After incubation, $10 \%$ ice cold trichloroacetic acid (TCA) was added and spun at $1000 \mathrm{Xg}$ for $10 \mathrm{~min}$. From the resulting supernatant, $0.5 \mathrm{ml}$ were separated and mixed with thiobarbutiric acid (TBA) $0.67 \%$ and the mixture was boiled for $10 \mathrm{~min}$. After boiling and cooling of the sample, $1 \mathrm{ml}$ of Milli-Q water was added and measured the absorbance at $532 \mathrm{~nm}$.

\subsection{SDS-PAGE and Western-blot}


For PKC- $\beta$-I detection, samples were diluted 1:1 with Laemmli loading buffer (BioRad, Hercules CA; 100 mM Tris-HCl pH 6.8, $70 \%$ glycerol, $2 \%$ SDS, $0.005 \%$ bromophenol blue, $10 \mathrm{mM} \beta$-mercaptoethanol). The samples were boiled for $5 \mathrm{~min}$, and for PKC- $\alpha$ detection, samples were diluted 1:1 with Laemmli loading buffer and incubated at $30{ }^{\circ} \mathrm{C}$ for $2 \mathrm{~h}$. The samples were loaded to standard $10 \%$ discontinuous gels. Then, the protein was transferred to nitrocellulose by standard procedure (Mini Trans-blot cell, Bio-Rad, Hercules CA). Western blotting was performed under standard conditions using anti-PKC- $\alpha$ or anti-PKC- $\beta$-I (Santa Cruz, Santa Cruz,,USA) as primary antibodies, at 1:500 and 1:400 dilution respectively, and anti-rabbit-horseradishperoxidase complex (Pierce, Rockford, USA) diluted to 1:30,000 as secondary antibody. Anti-GADPH primary antibodies were used as control (CalBiochem, San Diego, USA) at 1:3,000, using anti-mouse-horseradish-peroxidase complex (Pierce, Rockford, USA) diluted to 1:30,000 as secondary antibody. Protein visualization was performed using ECL-kit (Amersham-Bioscience, Little Chalfont, UK).

\section{Results}

\subsection{Proteomic analysis}


Preliminary analysis of the liver of female COMT-KO mice using traditional 2D proteomics techniques showed altered expression of thrombopoietin, glutathione-Stransferase, glutathione peroxidase, protein kinase C- $\alpha$ and $\alpha$-actin [35]. Based on these finding, a larger scale 2D-DIGE analysis was carried out comparing liver samples from COMT-KO and wild type mice of both sexes (Fig. 1). We detected intensity changes in several hundreds of spots. Changes in approximately 100 spots showed a significant $p$ value. Out of them, we were able to identify around 50 spots from the gels. The majority of them likely reflects compensatory mechanisms developed in the liver of COMT deficient mice,

In COMT-KO female liver, we were able to identify 7 up- and 7 down-regulated proteins. Notably, several are involved in the energy production, such as ATP synthase subunit $\beta$ and succinyl Coa ligase (which were up-regulated in COMT-KO $\sim 2$ - and 1.4-fold, respectively, in comparison with their wild type littermates, see Table 1), as well as fructose 1,6-diphosphate aldolase B and aldehyde dehydrogenase (both downregulated $\sim 1.5$-fold). Pyruvate carboxylase, an anabolic enzyme from the gluconeogenesis pathway, was also down-regulated $\sim 2$-fold. Of interest was that two key enzymes of the urea cycle, agrinase 1 and carbamoyl phosphate synthase 1 were upand down-regulated (1.4 and 1.6-fold) respectively.

Proteins related to the redox regulation and oxidative stress protection, such as carbonic anhydrase and glutathione S-transferase, were up-regulated in the mutant female liver, while 3-hydroxy anthranylate 3,4 dioxygenase, the last enzyme within the kynurenin pathway, was down regulated by a factor of 2 . Additionally, regucalcin, a protein which regulates $\mathrm{Ca}^{2+}$ signalling, was down-regulated 1.7-fold.

Structural proteins were also altered in female mice. Actin 1 decreased by 1.4fold and levels of cytokeratin 8 and cytokeratin 18 isoforms, main partners in 
hepatocyte cytoskeleton, were modified. While cytokeratine 8 was up-regulated $(\sim 1.5$ fold) cytokeratine 18 isoforms were either up- (spot $6,-1.9$ fold) or down regulated (spot 37, -1.6-fold).

In livers from KO male animals, the structural cytokeratins (-8, and -18) were also changed upon COMT disruption, but the enzymatic changes were different and more dramatic than those found in females. We identified three forms of selenium binding protein 2 (SBP2) that were differentially changed in COMT KO mouse liver (spots 5, 6 and 8 in Fig. 1; Table 2). The more acidic isoform (protein 5) was downregulated (-2.2 fold), but those SBP2 isoforms with higher pI (protein 6 and 8) were substantially up- regulated: $+2.4,+3.3$, respectively. Proteins 1 and 15 , identified as an elongation factor 2 and transferrin, were also substantially up-regulated (2.5- and 2-fold, respectively). Down-regulation of proteins $12,9 / 18$ and 6/16/17, identified as glutathione S-transferase (protein 12), cytokeratine 8 (proteins 9 and 18) and cytokeratine 18 (proteins 6,16 , and 17) was also observed (Table 1).

\subsection{Biochemical indicators of oxidative stress}

Many proteins found to be dysregulated by the disruption of COMT are related to hepatic stress. The possibility that COMT deficiency results in oxidative stress [1], prompted us to re-examine a number of liver redox homeostasis markers.

GSH:GSSG ratios of around 100 were found in for both genotypes irrespective of sex (Fig. 2A), confirming a redox balance consistent with previous reports [1]. Apparently, the levels of GSSG were increased in COMT KO samples but without statistic significance (Fig. 2B). The activities of lipid peroxidase were also higher in 
females than males. However, only homozygous males showed a slight but consistent increase over the wild type controls (Fig. 2C).

These findings, as well as the identification of changes in a number of glutathione-related enzymes in our proteome analysis, prompted us to assay also the activities of glutathione peroxidase and glutathione reductase (Fig. 3). We found that COMT deficient female mice showed a consistent $25 \%$ increase on glutathione peroxidase activity compared with their wild type littermates, while samples from males showed no significant difference (Fig. 3A). These activities were always slightly higher in males than females. Sex differences were also observed for glutathione reductase: males had considerably lower levels than females but there was no difference between the genotypes (Fig. 3B).

\subsection{Western blot analysis of protein kinase system}

Our proteomic analysis identified variations in different isoforms of either cytokeratin-8 or cytokeratin-18 in both sexes. These proteins are regulated by multiple phosphorylation [37] which has a net effect on the isoelectric point observed in 2-D electrophoresis. Additionally, since phosphorylation is a predicted modification for SBP2 [38], the different forms of SBP2 found to be modified by COMT disruption, may indicate changes in phosphorylation level as well. These hypotheses were verified by phosphoprotein detection in a 2-D gel electrophoresis, where both unphosphorylated and phosphorylated versions of SBP2 and cytokeratin 8 were detected (Fig. 4).

The changes in phosphorylation levels, in turn, may indicate changes in the phosphatases/kinases balance in the cell. Our preliminary proteome analysis [35] suggested that the expression of PKC- $\alpha$ may be altered by COMT deficiency and 
provided indications that other PKC isoforms may be altered as well. We were not able to detect any statistically significant change in PKC levels in our expanded proteomic analysis. However, using western blot analysis to probe directly the levels of two main PKC isoforms from COMT-KO mice livers we found that both liver PKC isoforms levels in COMT KO in males were decreased by about $50 \%$ (PKC- $\alpha$, Fig. 5A) and 75 $\%$ (PKC- $\beta$-I, Fig. 6A) compared to wild type littermates. We found no differences in PKC- $\alpha$ (Fig. 5B) and $\beta$-I isoforms (Fig. 6B) in the female mice.

\section{Discussion}

The main finding of this report is that mice with a disruption of the Comt gene, which causes a complete lack of COMT activity, display multiple and sex dependent metabolic changes, as shown by proteomic, biochemical or immunological assays. Some of these changes probably reflect compensatory responses. Some of these probably reflect compensatory responses. In that regard, it is notable that no changes in the machinery of synthesis or metabolism of dopamine, nor its receptor levels, have been reported previously for these mice $[2,6]$. It is important to mention that as a result of similarities of molecular weight and isoelectric point of among many proteins in the proteome, some changes have gone undetected in the present study. Nevertheless, a considerable number of changes could be identified in our proteomic study (see Tables 1 and 2).

One general conclusion from the enzymatic assays is that there is no remarkable oxidative stress in COMT deficient mouse liver, supporting our earlier results [1]. However, since high levels of L-dopa and dopamine are expected to be toxic, possibly through formation of ROS [18-20], we looked for compensatory mechanisms that could explain the lack of distinct oxidative stress. In this context, the changes described here 
can be described according to number of different perspectives. First, a number of the observed changes such as increases of proteins involved in detoxification or ROS metabolism appear to reflect compensatory mechanisms to cope with an apparent harsher environment in COMT disrupted liver,. Second, most of the proteins found dysregulated in the COMT disrupted livers, which are not necessarily connected to detoxification routes, are dysregulated in the same way in liver disease, toxicant response, or oxidative stress. Finally, our analysis indicates that several of the changes are sexually dimorphic. Our findings are summarized in Fig. 7. Female mice had milder changes in the proteome expression, but in several diverse pathways. On the other hand, the changes found in the male liver upon COMT disruption, were more dramatic but affected only a small subset of proteins, which were changed in females.

It is important to note, that a direct link between the changes discussed below, the lack of COMT and the changes in catecholamine metabolite levels previously reported $[2,6]$, especially regarding to the observed sexually dimorphic responses, remains to be demonstrated. Understanding the basis of the observed sexual dimorphisms and the contribution of oestrogens is particularly interesting, since oestrogen catabolism in the liver occurs through a COMT-mediated pathway [2].

COMT inhibitors are currently used along with L-dopa therapy in PD. Although COMT KO has been a model for COMT inhibition, the changes reported here, in a COMT-deficient animal model, may not necessarily reflect accurately the ones emerging as a result of acute pharmacological inhibition of COMT activity. There are indeed numerous developmental factors that might determine the outcome in the COMT KO mice, which are certainly not operative during therapy treatment. However, our results might help determine not only unaccounted side effects of COMT inhibitors, but 
also reasons to explain the decay over time of the effectiveness of this therapeutic regime.

\subsection{Proteome of female COMT knockout liver}

One remarkable finding in the proteome of the female COMT KO mice was the alteration in the hepatic levels of proteins involved in energy metabolism. We found evidence for dysregulation of several central enzymes in this pathway, such as ATP synthase, succinyl-CoA synthase, and fructose-bisphosphate aldolase. These changes might reflect differences in energy demand between genotypes. These enzymes have also in common that they are related to peroxisome proliferator activated receptor signalling (PPAR), and their expression in hepatic tissues is modified by tumour producing compounds which have peroxisome proliferation activity [see 39, 40 and 41]. In this respect COMT deficiency seems to mimic, in some fashion, carcinogenic activity.

Among the proteins dysregulated in liver from female knockout mice, carbonic anhydrase 3 and GST have documented connection to oxidative stress. Aryl hydrocarbon receptor (AHr) ligands, like PCB126, cause a dramatic reduction of carbonic anhydrase 3 in rat liver which could account for the suppression of the defence system for oxidative stress [42]. In addition, carbonic anhydrase 3 is significantly increased, in a sex dependent way, in alcohol intoxicated rats where the oxidative stress is evident [43]. GST's, conserved enzymes which detoxify several xenobiotic compounds, are reported to detoxify some of the secondary ROS [44, 45]. Both enzymes, along with glutathione peroxidase, are substantially increased in COMT disrupted female liver. This is in accordance with the relative increase of oxidized 
glutathione levels found in $\mathrm{KO}$ female liver, since both glutathione peroxidase and Stransferase have a common substrate: reduced glutathione. However, the overall balance of GSH:GSSH, an index of cellular oxidative stress, remains practically unchanged in the KO liver.

3-hydroxy-anthranilate 3,4-dioxygenase, which catalyzes the last step before the formation of quinolinic acid (QA), was decreased in COMT disrupted females. QA is a neurotoxin that induces neuronal calcium uptake leading to ROS generation through NMDA-receptor stimulation [46]. There are indications, that there are NMDA-receptor independent routes for ROS generation operating in the liver [47]. In aged rats, 3hydroxy-anthranilate 3,4-dioxygenase and other kynurenine pathway enzymes are progressively decreased [48]. The fact that 3-hydroxy-anthranilate 3,4-dioxygenase is decreased in COMT disrupted liver may lead to low QA levels and, in turn, a decreased risk of oxidative damage. It is of interest that carbamoyl-phosphate synthase I and arginase 1, enzymes within the urea cycle and found dysregulated in the liver of COMT disrupted female mice, have been found to be reduced in hepatocellular carcinoma [49, 50]. Three structural proteins, actin, and cytokeratin 8 and 18, are reported here to be dysregulated in female COMT knockout mice liver. Actin 1 ( $\beta$-actin, or ACTB), was down-regulated. This protein has been considered a housekeeping enzyme. However, it has been reported dysregulated in cancer cells [51], liver metastases [52], and in aged rats [53]. In COMT deleted mice, the changes in actin 1 might also be related to the response to stress in liver.

It should be noted that a number of the observed changes are not consistent with the idea of being compensatory in nature. This is the case, for example, for aldehyde dehydrogenase (ALDH2) and regucalcin, which are down regulated in the liver of female COMT KO mice. It has been established that ALDH2 plays a major role in 
acetaldehyde detoxification, and its deficiency increases vulnerability to oxidative stress [54]. In iron loaded hepatic cells, a decrease in ALDH2 activity [55] and expression [56] have been reported. On the other hand Pastorelli et al. [57] reported overexpression of ALDH2 in the 2,3,7,8-tetrachlorodibenzo-p-dioxin (TCDD) treated liver in several rat strains. With reference to regucalcin, it was observed in this latter study that it was considerably more abundant in TCDD-resistant rats than in those sensitive to the toxicant. Regucalcin is an intracellular $\mathrm{Ca}^{2+}$ regulator., which attenuates cell death caused by intracellular $\mathrm{Ca}^{2+}$ accumulation by enhancing plasma membrane $\mathrm{Ca}^{2+}$ pumping activity [58]. Pastorelli and co-workers [57] also speculate that the elevated basal levels of regucalcin may confer to the TCDD-resistant strain a protection against disruption of calcium homeostasis as might be mediated by TCDD. Therefore, the decrease of the levels of ALDH2 and regucalcin in the COMT disrupted liver may not be compensatory in nature, but on the contrary, these changes might make the liver more vulnerable to the cellular environment under COMT disruption..

\subsection{Status of the proteome on male liver from COMT disrupted animals}

The main changes found in male COMT-KO mice liver were down-regulation of selenium binding protein 2 (SBP2), and dysregulation of the hepatic specific cytokeratins 8/18 (CK8/18). Transferrin, albumin, and an elongation factor 2 were also found up-regulated.

SBP2 is associated with detoxification of chemical compounds. In the mouse, multiple forms of SBP2 are most abundantly expressed in the liver [59]. We found three protein spots of full-size SBP2, having different pI-values, to be differentially expressed 
in the liver of Comt gene disrupted male mice (Table I). These forms are differentially phosphorylated (Fig. 4). We found that SBP2a was down regulated (-2.2-fold), but SBP2b and SBP2c were up-regulated (+2.4- and +3.3-fold, respectively). SBP2 is the toxicity target for acetaminophen in the mouse liver [60-62]. SBP2 was reduced in the livers of the mice under atherogenic diet [63], in mice treated with peroxisome proliferators [64] and as a response of activators of peroxisome proliferator-activated receptor- $\alpha$ (PPAR $\alpha)$. PPAR $\alpha$ activation is important for the induction of cell specific pleiotropic responses, including liver tumours [65]. In addition, SBP2 may play a role in fibrosis [66]. Despite these findings, the precise biological function of SBP2 is scarcely known and its role in catecholamine metabolism is unidentified. It is remarkable that some changes in COMT-KO females were also in proteins known to be modified by peroxisome proliferators, like pyruvate carboxylase, the $\beta$ subunit of the ATP synthase, and aldehyde dehydrogenase.

CK8 (type II) and CK18 (type I) are the only CKs expressed in normal hepatocytes. Changes in CK intermediate filament expression are associated with an abnormal cellular behaviour $[67,68]$. There is a relationship between CK8/18 filaments and the formation of Mallory bodies, hyaline and keratin containing inclusion particles associated with hepatic damage [68]. The CK intermediate filament network is important for the structural integrity of hepatocytes [69], but CK proteins seem to have important non-structural functions as well, including protection from toxic stress in a number of complicated situations [69-72]. Our results show that in the male COMT KO liver, the amounts of CK8 and CK18 are reduced to half and one third, respectively, compared with these levels detected in the wild type controls (Table I). Interestingly, we identified several protein spots, such as CK8 (proteins 7, 16 and 17) and CK18 (proteins 9 and 18), probably with different phosphorylation levels, but all with parallel changes. 
Phosphorylation is one of the most important regulatory protein modifications, particularly in response to external stimuli. Hyper-phosphorylation of CKs is involved in the cellular stress response and seems to play a role in the protection from hepatotoxicity $[69,73]$. In human alcoholic hepatitis, phosphorylation of CKs at multiple sites and accumulation of phosphorylated CKs in Mallory bodies, have been reported [65]. Griseofulvin- or 3,5-diethoxycarbonyl-1,4-dihydrocollidine-treated animals (alcoholic hepatitis models) showed an increase of the more acidic isoelectric CK variants due to increased phosphorylation $[70,74,75]$. The relation of these findings to the lack of COMT is currently poorly understood, but it seems that the decrease in these cytokeratins might be a sign of predisposition to hepatotoxic injury and increase ability to form Mallory bodies in the liver of COMT disrupted male mice. However, an opposite pattern is evident in female COMT KO mice, where the levels of these CK's, with the exception of one isoform of CK18 (which is slightly decreased, spot 37 in Table 1), where found up-regulated. The mechanistic basis of this difference is not understood, but it might be due to different response to oxidative between sexes (see below)..

\subsection{The kinase connection}

Protein kinases have a central role in practically all functions of the cell, including the response to stress. Considering our biochemical results with sex selective changes in PKC isoforms in COMT KO mice, some explanations seem feasible. It has been reported that PKC- $\alpha$ and $-\beta$ are activated by ROS, by means of cysteine oxidation of the zinc in the regulatory domain $[76,77]$. The modification is translated to interactions between the regulatory and catalytic domains, resulting in enzyme activation. In 
addition, an activation of PKC- $\alpha$ and $-\beta$-I isoforms has been reported in diabetic oxidative stress [78]. As a supporting argument, it can be mentioned that PKC- $\beta$ deficient mice show a reduction of the diabetes-induced oxidative stress [78]. These effects are due, in part, to the decrease of NADPH oxidase activity [79]. PKC- $\beta$ deficient mice show unaffected levels of other PKC isoforms, but the basal and the NADPH stimulated levels of oxygen consumption were reduced. Such results link directly the decrease of PKC- $\beta$ and the reduction of oxidative stress. Our results suggest a taming of oxidative stress in COMT deficient mice, among other possibilities, through a decrease on PKC- $\alpha$ and PKC- $\beta$ expression. This might be reflected in the changes on the relative proportions of protein isoforms with certain phosphorylation level.

\subsection{COMT disruption and sexual dimorphism}

The liver redox metabolism is known to be sexually dimorphic. In mitochondria, there is a higher antioxidant gene expression in females than males, and the former sex have a $40 \%$ higher peroxide formation. Our enzymatic and immunoblotting data show that some indicators of cell redox balance in the liver are indeed changed in a sex specific manner due to lack of COMT. Homozygous males showed an slight increase of oxidised glutathione an also o lipid peroxidation was somehow increased. COMT (-/-) homozygous females showed a modest increase in glutathione peroxidase activity, while this change was absent in males. Changes associated with COMT deficiency were not observed when assaying glutathione reductase. Other studies have reported, in agreement with ours, higher importance of glutathione metabolism and general antioxidants defences in females than in males $[1,80]$. 
In females, the shift of redox balance caused by COMT deletion is visualized as an up-regulation of glutathione S-transferase and carbonic anhydrase III, and possibly as an increase of total GSH. This is in agreement with previous studies [81-83], pointing to a general glutathione mobilization as an adaptation to a new environment. Unexpectedly indeed, we observed that in COMT KO males, glutathione S-transferase was downregulated. The meaning of this change remains elusive, but it might account for a higher sensitivity of male than female liver to toxic damage.

The sexually dimorphic changes in the content of hepatic intermediate filament components, CK-8 and CK-18, in the COMT KO mice are more difficult to interpret. While, on average, the levels of these proteins are decreased in males, they are increased in females. The series of events linking the lack of COMT and the CK's regulatory elements are unknown. Notably, changes in these particular cytoskeletal proteins have been linked to conditions which distress liver homeostasis, and this is probably the case in this mouse line. The sex-related difference might be indicative of the different strategies employed by the female organism to cope with stress compared to males.

Sex differences in the responses of Comt gene disruption make the importance of the threshold marker of oxidative stress relevant. During oxidation and excessive thiol consumption, the aromatic amino acids may become the key targets of toxicity. Ldopa is a major product of tyrosine targeted radical reactions [84]. L-dopa itself is a natural cellular constituent and a dopamine precursor, but its levels are very low compared to tyrosine levels. Recently, it has been reported that under conditions where the ratio L-dopa/tyrosine is increased, like in the treatment of PD [85], L-dopa is able to be incorporated in proteins instead of tyrosine $[86,87]$. The increase of L-dopa 
containing proteins has been proposed to be a trigger for antioxidant defence [88] which might be operative in COMT-KO livers.

COMT is involved in estrogen metabolism that has obvious sex related differences [2]. Furthermore, it is of interest that AHr antagonists, like TCDD, increase the hepatic activity of COMT for 2- and 4- hydroxyl 17- $\beta$-estradiol methylation, by an unknown mechanism, and that there are studies showing that a cross-talk between the AhR system and the peroxisome proliferator activation receptor system, as well as with other nuclear receptor systems, is operative in normal and stressed conditions, see [89] Therefore it is logical that most of the changes recorded in our present study reflect changes in $\mathrm{AhR}$ and peroxisome proliferator activation receptor systems.

We conclude, on one hand, that the livers of COMT deficient mice do not express obvious stress because of the prevalence of effective compensatory mechanisms. These defences involve detoxification of related proteins and protein kinases in a sex dependent manner. That the induction of compensatory mechanism is mostly seen in males, may be related to the fact that the normal levels of liver COMT are higher in males than females. Induction of compensatory mechanism may explain different phenotype-gene-dosage depending phenomena. This hypothesis points to a threshold necessary to surpass in order to active the compensatory machinery. According with this hypothesis we suggest that the loss of COMT activity in males is sufficient to induce the compensatory mechanism while, in females, which naturally express lower COMT activity levels, the disruption of the gene does not overcome the threshold. On the other hand, and due to the fact that the protein expression changes found in our study mimic those found in hepatic stress in general, it appears that the liver of COMT KO mice is more vulnerable. This might due to increase in catecholamine levels, but also due to the accumulation of other environmental 
compounds, normally metabolized by COMT, or endogenous catechol oestrogens also affected by the inactivation of the enzyme. Indeed, increased levels of 2methylestradiol, a product of COMT,is thought to have an impact on ovarian and uterine processes [90] where oxidative stress could play a role [91]. Additional studies are necessary to unravel potential connections along these lines.

\section{Acknowledgments}

We thank Ms. Marjo Vaha and Ms. Anna Niemi for excellent technical support, and to the Proteomic facility of the Centro de Investigación Príncipe Felipe, member of the Spanish ProteoRed, for outstanding proteomic analysis and support. This work was supported by the Sigrid Juselius Foundation and the Finnish Academy (grant No. 210758 to PTM), and by grants from the Fundación Centro de Investigación Príncipe Felipe (JT-L and JAG-H), and the Ministerio de Educación y Ciencia Ramon y Cajal Programme (JAG-H).

\section{REFERENCES}

[1] Forsberg MM, Juvonen RO, Helisalmi P, Leppanen J, Gogos JA, Karayiorgou $\mathrm{M}$, et al. Lack of increased oxidative stress in catechol-O-methyltransferase (COMT)deficient mice. Naunyn Schmiedebergs Arch Pharmacol 2004;370:279-89.

[2] Männistö PT, Kaakkola S. Catechol-O-methyltransferase (COMT): biochemistry, molecular biology, pharmacology, and clinical efficacy of the new selective COMT inhibitors. Pharmacol Rev 1999;51:593-628.

[3] Jiang H, Xie T, Ramsden DB, Ho SL. Human catechol-O-methyltransferase down-regulation by estradiol. Neuropharmacology 2003;45:1011-8. 
[4] Xie T, Ho SL, Ramsden D. Characterization and implications of estrogenic down-regulation of human catechol-O-methyltransferase gene transcription. Mol Pharmacol 1999;56:31-8.

[5] Gogos JA, Morgan M, Luine V, Santha M, Ogawa S, Pfaff D, et al. Catechol-Omethyltransferase-deficient mice exhibit sexually dimorphic changes in catecholamine levels and behavior. Proc Natl Acad Sci U S A 1998;95:9991-6.

[6] Huotari M, Gogos JA, Karayiorgou M, Koponen O, Forsberg M, Raasmaja A, et al. Brain catecholamine metabolism in catechol-O-methyltransferase (COMT)-deficient mice. Eur J Neurosci 2002;15:246-56.

[7] Huotari M, Santha M, Lucas LR, Karayiorgou M, Gogos JA, Männistö PT. Effect of dopamine uptake inhibition on brain catecholamine levels and locomotion in catechol-O-methyltransferase-disrupted mice. J Pharmacol Exp Ther 2002;303:1309-16. [8] Yavich L, Forsberg MM, Karayiorgou M, Gogos JA, Männistö PT. Site-specific role of catechol-O-methyltransferase in dopamine overflow within prefrontal cortex and dorsal striatum. J Neurosci 2007;27:10196-209.

[9] Huotari M, García-Horsman JA, Karayiorgou M, Gogos JA, Männistö PT. Damphetamine responses in catechol-O-methyltransferase (COMT) disrupted mice. Psychopharmacology (Berl) 2004;172:1-10.

[10] Babovic D, O'Tuathaigh CM, O'Sullivan GJ, Clifford JJ, Tighe O, Croke DT, et al. Exploratory and habituation phenotype of heterozygous and homozygous COMT knockout mice. Behav Brain Res 2007;183:236-9.

[11] Babovic D, O'Tuathaigh CM, O'Connor AM, O'Sullivan GJ, Tighe O, Croke DT, et al. Phenotypic characterization of cognition and social behavior in mice with heterozygous versus homozygous deletion of catechol-O-methyltransferase.

Neuroscience 2008;155:1021-9. 
[12] Papaleo F, Crawley JN, Song J, Lipska BK, Pickel J, Weinberger DR, et al.

Genetic dissection of the role of catechol-O-methyltransferase in cognition and stress reactivity in mice. J Neurosci 2008;28:8709-23.

[13] Helkamaa T, Männistö PT, Rauhala P, Cheng ZJ, Finckenberg P, Huotari M, et al. Resistance to salt-induced hypertension in catechol-O-methyltransferase-genedisrupted mice. J Hypertens 2003;21:2365-74.

[14] Tammimäki A, Forsberg M, Karayiorgou M, Gogos JA, Männistö PT. Increase in free choice oral ethanol self-administration in male mice with catechol-Omethyltransferase gene disruption. Basic Clin Pharmacol Toxicol 2008:In press. [15] Kambur O, Männistö PT, Viljakka K, Reenilä I, Lemberg K, Kontinen VK, et al. Stress-Induced Analgesia and Morphine Responses Are Changed in Catechol-Omethyltransferase-Deficient Male Mice. Basic Clin Pharmacol Toxicol 2008;103:36773.

[16] Fahn S. Levodopa-induced neurotoxicity - Does it represent a problem for the treatment of Parkinson's disease? CNS Drugs 1997;8:376-93.

[17] Olanow CW. Oxidation Reactions in Parkinsons-Disease. Neurology 1990;40:32-7.

[18] Basma AN, Morris EJ, Nicklas WJ, Geller HM. L-Dopa Cytotoxicity to Pc12

Cells in Culture Is Via Its Autoxidation. J Neurochem 1995;64:825-32.

[19] Mena MA, Pardo B, Casarejos MJ, Fahn S, Deyebenes JG. Neurotoxicity of Levodopa on Catecholamine-Rich Neurons. Mov Disord 1992;7:23-31.

[20] Michel PP, Hefti F. Toxicity of 6-Hydroxydopamine and Dopamine for Dopaminergic-Neurons in Culture. J Neurosci Res 1990;26:428-35.

[21] Morel Y, Barouki R. Repression of gene expression by oxidative stress. Biochem J 1999;342:481-96. 
[22] Riederer P, Sofic E, Rausch WD, Schmidt B, Reynolds GP, Jellinger K, et al.

Transition-Metals, Ferritin, Glutathione, and Ascorbic-Acid in Parkinsonian Brains. J Neurochem 1989;52:515-20.

[23] Sian J, Dexter DT, Lees AJ, Daniel S, Agid Y, Javoyagid F, et al. Alterations in Glutathione Levels in Parkinsons-Disease and Other Neurodegenerative Disorders Affecting Basal Ganglia. Ann Neurol 1994;36:348-55.

[24] Sian J, Dexter DT, Lees AJ, Daniel S, Jenner P, Marsden CD. GlutathioneRelated Enzymes in Brain in Parkinsons-Disease. Ann Neurol 1994;36:356-61.

[25] Dexter DT, Wells FR, Lees AJ, Agid F, Agid Y, Jenner P, et al. Increased Nigral Iron Content and Alterations in Other Metal-Ions Occurring in Brain in ParkinsonsDisease. J Neurochem 1989;52:1830-6.

[26] Sofic E, Riederer P, Heinsen H, Beckmann H, Reynolds GP, Hebenstreit G, et al. Increased Iron(Iii) and Total Iron Content in Post-Mortem Substantia Nigra of Parkinsonian Brain. J Neural Transm 1988;74:199-205.

[27] Sofic E, Lange KW, Jellinger K, Riederer P. Reduced and Oxidized Glutathione in the Substantia-Nigra of Patients with Parkinsons-Disease. Neurosci Lett $1992 ; 142: 128-30$.

[28] Jenner P, Olanow CW. Oxidative stress and the pathogenesis of Parkinson's disease. Neurology 1996;47:S161-S70.

[29] Olanow CW, Tatton WG. Etiology and pathogenesis of Parkinson's disease. Annu Rev Neurosci 1999;22:123-44.

[30] Kopin IJ. Catecholamine Metabolism - Basic Aspects and Clinical-Significance. Pharmacological Reviews 1985;37:333-64. 
[31] Miller JW, Selhub J, Joseph JA. Oxidative damage caused by free radicals produced during catecholamine autoxidation: Protective effects of O-methylation and melatonin. Free Radic Biol Med 1996;21:241-9.

[32] Nappi AJ, Vass E. Hydroxyl radical formation via iron-mediated Fenton chemistry is inhibited by methylated catechols. Biochim Biophys Acta 1998;1425:15967.

[33] Gerlach M, Xiao AY, Kuhn W, Lehnfeld R, Waldmeier P, Sontag KH, et al. The central catechol-O-methyltransferase inhibitor tolcapone increases striatal hydroxyl radical production in L-DOPA/carbidopa treated rats. J Neural Transm 2001;108:189204.

[34] Lyras L, Zeng BY, McKenzie G, Pearce RKB, Halliwell B, Jenner P. Chronic high dose L-DOPA alone or in combination with the COMT inhibitor entacapone does not increase oxidative damage or impair the function of the nigro-striatal pathway in normal cynomologus monkeys. J Neural Transm 2002;109:53-67.

[35] García-Horsman JA, Auriola S, Männistö PT. Analysis of the proteome of COMT knockout mice. Eur J Pharm Sci 2003;19:S31-S.

[36] Laird PW, Zijderveld A, Linders K, Rudnicki MA, Jaenisch R, Berns A. Simplified mammalian DNA isolation procedure. Nucleic Acids Res 1991;19:4293. [37] Omary MB, Ku NO, Tao GZ, Toivola DM, Liao J. "Heads and tails" of intermediate filament phosphorylation: multiple sites and functional insights. Trends Biochem Sci 2006;31:383-94.

[38] Mattow J, Demuth I, Haeselbarth G, Jungblut PR, Klose J. Selenium-binding protein 2 , the major hepatic target for acetaminophen, shows sex differences in protein abundance. Electrophoresis 2006;27:1683-91. 
[39] Jitrapakdee S, Vidal-Puig A, Wallace JC. Anaplerotic roles of pyruvate carboxylase in mammalian tissues. Cell Mol Life Sci 2006;63:843-54.

[40] Chevalier S, Macdonald N, Tonge R, Rayner S, Rowlinson R, Shaw J, et al. Proteomic analysis of differential protein expression in primary hepatocytes induced by EGF, tumour necrosis factor alpha or the peroxisome proliferator nafenopin. Eur J Biochem 2000;267:4624-34.

[41] Feige JN, Gelman L, Michalik L, Desvergne B, Wahli W. From molecular action to physiological outputs: peroxisome proliferator-activated receptors are nuclear receptors at the crossroads of key cellular functions. Prog. lipid Res. 2006:45:120-159. [42] Ishii Y, Akazawa D, Aoki Y, Yamada H, Oguri K. Suppression of carbonic anhydrase III mRNA level by an aryl hydrocarbon receptor ligand in primary cultured hepatocytes of rat. Biol Pharm Bull 2005;28:1087-90.

[43] Parkkila S, Halsted CH, Villanueva JA, Väänänen HK, Niemelä O. Expression of testosterone-dependent enzyme, carbonic anhydrase III, and oxidative stress in experimental alcoholic liver disease. Dig Dis Sci 1999;44:2205-13.

[44] Gallagher EP, Gardner JL, Barber DS. Several glutathione S-transferase isozymes that protect against oxidative injury are expressed in human liver mitochondria. Biochem Pharmacol 2006;71:1619-28.

[45] Ravichandran V, Seres T, Moriguchi T, Thomas JA, Johnston RB, Jr. Sthiolation of glyceraldehyde-3-phosphate dehydrogenase induced by the phagocytosisassociated respiratory burst in blood monocytes. J Biol Chem 1994;269:25010-5.

[46] Jacquard C, Trioulier Y, Cosker F, Escartin C, Bizat N, Hantraye P, et al. Brain mitochondrial defects amplify intracellular $[\mathrm{Ca} 2+]$ rise and neurodegeneration but not Ca2+ entry during NMDA receptor activation. FASEB J 2006;20:1021-3. 
[47] Müller AC, Dairam A, Limson JL, Daya S. Mechanisms by which acyclovir reduces the oxidative neurotoxicity and biosynthesis of quinolinic acid. Life Sci 2007;80:918-25.

[48] Comai S, Costa CV, Ragazzi E, Bertazzo A, Allegri G. The effect of age on the enzyme activities of tryptophan metabolism along the kynurenine pathway in rats. Clin Chim Acta 2005;360:67-80.

[49] Kinoshita M, Miyata M. Underexpression of mRNA in human hepatocellular carcinoma focusing on eight loci. Hepatology 2002;36:433-8.

[50] Yokoyama Y, Kuramitsu Y, Takashima M, Iizuka N, Toda T, Terai S, et al. Proteomic profiling of proteins decreased in hepatocellular carcinoma from patients infected with hepatitis C virus. Proteomics 2004;4:2111-6.

[51] Khimani AH, Mhashilkar AM, Mikulskis A, O'Malley M, Liao J, Golenko EE, et al. Housekeeping genes in cancer: normalization of array data. Biotechniques 2005;38:739-45.

[52] Blanquicett C, Johnson MR, Heslin M, Diasio RB. Housekeeping gene variability in normal and carcinomatous colorectal and liver tissues: applications in pharmacogenomic gene expression studies. Anal Biochem 2002;303:209-14.

[53] Chen J, Rider DA, Ruan R. Identification of valid housekeeping genes and antioxidant enzyme gene expression change in the aging rat liver. J Gerontol A Biol Sci Med Sci 2006;61:20-7. 
[54] Ohsawa I, Nishimaki K, Yasuda C, Kamino K, Ohta S. Deficiency in a mitochondrial aldehyde dehydrogenase increases vulnerability to oxidative stress in PC12 cells. J Neurochem 2003;84:1110-7.

[55] Britton RS, O'Neill R, Bacon BR. Hepatic mitochondrial malondialdehyde metabolism in rats with chronic iron overload. Hepatology 1990;11:93-7.

[56] Petrak J, Myslivcova D, Man P, Cmejla R, Cmejlova J, Vyoral D. Proteomic analysis of iron overload in human hepatoma cells. Am J Physiol Gastrointest Liver Physiol 2006;290:G1059-66.

[57] Pastorelli R, Carpi D, Campagna R, Airoldi L, Pohjanvirta R, Viluksela M, et al. Differential expression profiling of the hepatic proteome in a rat model of dioxin resistance: correlation with genomic and transcriptomic analyses. Mol Cell Proteomics 2006;5:882-94.

[58] Yamaguchi M. Role of regucalcin in calcium signaling. Life Sci 2000;66:1769 80.

[59] Lanfear J, Fleming J, Walker M, Harrison P. Different patterns of regulation of the genes encoding the closely related $56 \mathrm{kDa}$ selenium- and acetaminophen-binding proteins in normal tissues and during carcinogenesis. Carcinogenesis 1993;14:335-40. [60] Hoivik DJ, Manautou JE, Tveit A, Mankowski DC, Khairallah EA, Cohen SD. Evidence suggesting the $58-\mathrm{kDa}$ acetaminophen binding protein is a preferential target for acetaminophen electrophile. Fundam Appl Toxicol 1996;32:79-86.

[61] Pumford NR, Hinson JA, Benson RW, Roberts DW. Immunoblot Analysis of Protein Containing 3-(Cystein-S-Y1)Acetaminophen Adducts in Serum and Subcellular Liver Fractions from Acetaminophen-Treated Mice. Toxicol Appl Pharmacol 1990;104:521-32. 
[62] Pumford NR, Martin BM, Hinson JA. A metabolite of acetaminophen covalently binds to the $56 \mathrm{kDa}$ selenium binding protein. Biochem Biophys Res Commun 1992;182:1348-55.

[63] Park JY, Seong JK, Paik YK. Proteomic analysis of diet-induced hypercholesterolemic mice. Proteomics 2004;4:514-23.

[64] Giometti CS, Liang X, Tollaksen SL, Wall DB, Lubman DM, Subbarao V, et al. Mouse liver selenium-binding protein decreased in abundance by peroxisome proliferators. Electrophoresis 2000;21:2162-9.

[65] Chu RY, Lim H, Brumfield L, Liu H, Herring C, Ulintz P, et al. Protein profiling of mouse livers with peroxisome proliferator-activated receptor alpha activation. Mol Cell Biol 2004;24:6288-97.

[66] Henkel C, Roderfeld M, Weiskirchen R, Scheibe B, Matern S, Roeb E. Identification of fibrosis-relevant proteins using DIGE (Difference in gel electrophoresis) in different models of hepatic fibrosis. Zeitschrift Fur GastroenterologieZeitschrift Fur Gastroenterologie 2005;43:23-9.

[67] $\mathrm{Ku} \mathrm{NO}$, Omary MB. Effect of mutation and phosphorylation of type I keratins on their caspase-mediated degradation. J Biol Chem 2001;276:26792-8.

[68] Stumptner C, Omary MB, Fickert P, Denk H, Zatloukal K. Hepatocyte cytokeratins are hyperphosphorylated at multiple sites in human alcoholic hepatitis and in a Mallory body mouse model. Am J Pathol 2000;156:77-90.

[69] Omary $\mathrm{MB}, \mathrm{Ku} \mathrm{NO}$. Intermediate filament proteins of the liver: emerging disease association and functions. Hepatology 1997;25:1043-8.

[70] Denk H, Stumptner C, Zatloukal K. Mallory bodies revisited. J Hepatol 2000;32:689-702. 
[71] Ku NO, Michie SA, Soetikno RM, Resurreccion EZ, Broome RL, Omary MB. Mutation of a major keratin phosphorylation site predisposes to hepatotoxic injury in transgenic mice. J Cell Biol 1998;143:2023-32.

[72] Zatloukal K, Stumptner C, Lehner M, Denk H, Baribault H, Eshkind LG, et al. Cytokeratin 8 protects from hepatotoxicity, and its ratio to cytokeratin 18 determines the ability of hepatocytes to form mallory bodies. Am J Pathol 2000;156:1263-74.

[73] Ku NO, Liao J, Chou CF, Omary MB. Implications of intermediate filament protein phosphorylation. Cancer Metastasis Rev 1996;15:429-44.

[74] Cadrin M, Anderson NM, Aasheim LH, Kawahara H, Franks DJ, French SW. Modifications in Cytokeratin and Actin in Cultured Liver-Cells Derived from Griseofulvin-Fed Mice. Lab Invest 1995;72:453-60.

[75] Salmhofer H, Rainer I, Zatloukal K, Denk H. Posttranslational Events Involved in Griseofulvin-Induced Keratin Cytoskeleton Alterations. Hepatology 1994;20:731-40. [76] Gopalakrishna R, Jaken S. Protein kinase C signaling and oxidative stress. Free Radic Biol Med 2000;28:1349-61.

[77] Kass GEN, Duddy SK, Orrenius S. Activation of Hepatocyte Protein Kinase-C by Redox-Cycling Quinones. Biochem J 1989;260:499-507.

[78] Ohshiro Y, Ma RC, Yasuda Y, Hiraoka-Yamamoto J, Clermont AC, Isshiki K, et al. Reduction of diabetes-induced oxidative stress, fibrotic cytokine expression, and renal dysfunction in protein kinase C beta - Null mice. Diabetes 2006;55:3112-20.

[79] Dekker LV, Leitges M, Altschuler G, Mistry N, McDermott A, Roes J, et al. Protein kinase C-beta contributes to NADPH oxidase activation in neutrophils. Biochem J 2000;347:285-9. 
[80] Mitchell AE, Morin D, Lakritz J, Jones AD. Quantitative profiling of tissue- and gender-related expression of glutathione S-transferase isoenzymes in the mouse. Biochem J 1997;325:207-16.

[81] Jornot L, Junod AF. Hyperoxia, unlike phorbol ester, induces glutathione peroxidase through a protein kinase C-independent mechanism. Biochem J $1997 ; 326: 117-23$.

[82] Pinkus R, Weiner LM, Daniel V. Role of Quinone-Mediated Generation of Hydroxyl Radicals in the Induction of Glutathione-S-Transferase Gene-Expression. Biochemistry 1995;34:81-8.

[83] Raza H, Robin MA, Fang JK, Avadhani NG. Multiple isoforms of mitochondrial glutathione S-transferases and their differential induction under oxidative stress.

Biochem J 2002;366:45-55.

[84] Gieseg SP, Simpson JA, Charlton TS, Duncan MW, Dean RT. Protein-bound 3,4-dihydroxyphenylalanine is a major reductant formed during hydroxyl radical damage to proteins. Biochemistry 1993;32:4780-6.

[85] Rodgers KJ, Hume PM, Morris JGL, Dean RT. Evidence for L-dopa incorporation into cell proteins in patients treated with levodopa. J Neurochem 2006;98:1061-7.

[86] Ozawa K, Headlam MJ, Mouradov D, Watt SJ, Beck JL, Rodgers KJ, et al. Translational incorporation of L-3,4-dihydroxyphenylalanine into proteins. FEBS J 2005;272:3162-71.

[87] Rodgers KJ, Hume PM, Dunlop RA, Dean RT. Biosynthesis and turnover of DOPA-containing proteins by human cells. Free Radic Biol Med 2004;37:1756-64. 
[88] Nelson M, Foxwell AR, Tyrer P, Dean RT. Protein-bound 3,4-dihydroxyphenylanine (DOPA), a redox-active product of protein oxidation, as a trigger for antioxidant defences. Int J Biochem Cell Biol 2007;39:879-89.

[89] Hanlon PR, Ganem LG, Cho YC, Yamamoto M, Jefcoate CR. AhR- and ERKdependent pathways function synergistically to mediate 2,3,7,8-tetrachlorodibenzo-pdioxin suppression of peroxisome proliferator-activated receptor-gamma1 expression and subsequent adipocyte differentiation. Toxicol Appl Pharmacol 2003;189:11-27. [90] Kanasaki K, Palmsten K, Sugimoto H, Ahmad S, Hamano Y, Xie L, Parry S, Augustin HG, Gattone VH, Folkman J, Strauss JF, Kalluri R. Deficiency in catechol-Omethyltransferase and 2-methoxyoestradiol is associated with pre-eclampsia. Nature $2008 ; 4531117-21$

[91] Banerjee S, Randeva H, Chambers AE. Mouse models for preeclampsia: disruption of redox-regulated signaling. Reprod Biol Endocrinol 2009; In press 


\section{Figure Legends}

Figure 1. Representative 2-D-DIGE gels showing differentially expressed protein spots in COMT deficient mice with respect to wild type. A. Females, B. Males. Green (Cy3 dye) wild type proteins; Red (Cy5 dye) KO proteins; blue (Cy2) standard proteins (WT:KO mix 50:50\%). Numbers refer to the specific spots in tables 1 and 2.

Figure 2. Glutathione (A and B) and lipid peroxidase (C) levels in female () and male ( $ぇ)$ liver samples from COMT (-/-) homozygotes (slashed bars) compared with wild type (clear bars) mice. $p$-values $<0.01, * *$.

Figure 3. Glutathione peroxidase (A), and glutathione reductase (B), and lipid peroxidase (c) activities in liver homogenates from females (first pair) and males (second pair), comparing COMT knockout (slashed bars) and wild type (clear bars) mice. $p$-values $<0.001$, ***.

Figure 4. 2-D-DIGE of liver total protein from male wt stained for protein (Spyro red) and phosphate (proQ, in green). Identity of the spots: 5, 6 and 8, selenium binding protein $2 ; 7,17$ and 16 cytokeratin 8 .

Figure 5. Levels of protein kinase C-alpha, determined by western-blot band density, in male (A) and female (B) liver from wild type (WT, white bars) and COMT-KO (KO, gray bars) mice. PKC- $\alpha$ levels were standardised to GADPH levels. $* * p$-value $=$ 0.0038. Representative western blots appear in the bottom of each graph.

Figure 6. Levels of protein kinase C-beta I, determined by western-blot band density, in male (A) and female (B) liver from wild type (WT, white bars) and COMT-KO (KO, 
gray bars) mice. PKC- $\beta$-I levels were standardised to GADPH levels. ** $p$-value $=$ 0.0076. Representative western blots appear in the bottom of each graph.

Figure 7. Summary of protein expression changes in mouse liver from COMT-KO mice. Changes were found in metabolic, regulatory and structural proteins and they were sex specific. The altered expression found in this study have relations with changes found before in disease or stress situations, as indicated by colour coding: yellow background, proteins altered in hepatic cancer; pink background, proteins altered by toxicants; navy framed, proteins modulated by peroxisome proliferators; red framed, proteins changed by oxidative stress. Note that some proteins were modified in more than one of the above situations. For references and discussion, see the text. $\mathrm{ADH}$, aldehyde dehydrogenase; ATP synth, ATP synthase subunit $\beta$, AldoB, fructose 1,6-diphosphate aldolase B; Actin, $\beta$-actin; Arg I, arginase I; CAIII, carbonic anhydrase 3, CK-8 -18, cytokeratin-8 and -18; CPSI, carbamoyl-phosphate synthase I; EF2, elongation factor-2; GST, glutathione-s-transferase; PC, pyruvate carboxylase; RGN, Regucalcin; SBP2, selenium binding protein-2; Suc-CoA Synth., Succinyl-CoA synthase. 
Table 1 2D-DIGE identified proteins with significative level change in COMT knockout vs. wild type liver in female mice.

\begin{tabular}{|c|c|c|c|c|c|}
\hline Spot $^{a}$ & $\begin{array}{l}\text { Protein name } \\
\text { (accession no.) }\end{array}$ & Function & $\mathbf{k D a} / \mathbf{P I}$ & Ratio $^{e}$ & p-value \\
\hline \multicolumn{6}{|c|}{ Up-regulated proteins } \\
\hline 1 & $\begin{array}{l}\text { ATP synthase } \beta \text { subunit } \\
\text { (P56480) }\end{array}$ & $\begin{array}{l}\text { Catalytic subunit of mitochondrial membrane ATP synthase. Produces ATP from ADP and phosphate dependent on the } \\
\text { respiratory chain generated membrane potential. }\end{array}$ & $\begin{array}{r}56 / 5.05^{\mathrm{c}} \\
\underline{56 / 5.2^{\mathrm{d}}}\end{array}$ & 2.14 & 0.014 \\
\hline 2 & $\begin{array}{l}\text { ATP synthase } \beta \text { subunit } \\
\text { (P56480) }\end{array}$ & See above & $\begin{array}{l}56 / 5.0 \\
56 / 5.2\end{array}$ & 2.07 & 0.017 \\
\hline 3 & $\begin{array}{l}\text { ATP synthase } \beta \text { subunit } \\
\text { (P56480) }\end{array}$ & See above & $\begin{array}{l}56 / 5.2 \\
\underline{56 / 5.2}\end{array}$ & 2.07 & 013 \\
\hline 4 & $\begin{array}{l}\text { Cytokeratin-8 } \\
\text { (P11679) }\end{array}$ & $\begin{array}{l}\text { Cytoskeletal intermediate filament protein. Keratin- } 8 \text { associates with keratin-18. Phosphorylation on serine residues is enhanced } \\
\text { during EGF stimulation and mitosis. }\end{array}$ & $\begin{array}{r}55 / 6 \\
55 / 5.7 \\
\end{array}$ & 2.04 & 0.0081 \\
\hline 5 & $\begin{array}{l}\text { Carbonic anhydrase } 3 \\
\quad(\mathrm{P} 16015)\end{array}$ & Reversible hydration of carbon dioxide. & $\begin{array}{l}30 / 7.5 \\
30 / 6.9\end{array}$ & 1.93 & 0.04 \\
\hline 6 & $\begin{array}{l}\text { Cytokeratin-18 } \\
\quad(\text { P05784) }\end{array}$ & $\begin{array}{l}\text { Cytoskeletal intermediate filament protein. Keratin- } 18 \text { associates with keratin- } 8 \text {. When phosphorylated, plays a role in filament } \\
\text { reorganization.. Involved in the uptake of thrombin-antithrombin complexes by hepatic cells. }\end{array}$ & $\begin{array}{l}48 / .5 .2 \\
\underline{48 / 5.2}\end{array}$ & 1.91 & 0.024 \\
\hline 7 & $\begin{array}{l}\text { ATP synthase } \beta \text { subunit } \\
\quad(\text { P56480) }\end{array}$ & See above & $\begin{array}{r}56 / 5.3 \\
\underline{56 / 5.2}\end{array}$ & 1.91 & 0.012 \\
\hline 8 & $\begin{array}{l}\text { Cytokeratin-8 } \\
\text { (P11679) }\end{array}$ & See above & $\begin{array}{l}55 / 6.1 \\
55 / 5.7 \\
\end{array}$ & 1.81 & 0.00096 \\
\hline 9 & $\begin{array}{l}\text { Cytokeratin-8 } \\
\text { (P11679) }\end{array}$ & See above & $\begin{array}{l}55 / 6.2 \\
\underline{55 / 5.7}\end{array}$ & 1.76 & 0.013 \\
\hline 10 & $\begin{array}{l}\text { Cytokeratin-8 } \\
\text { (P11679) }\end{array}$ & See above & $\begin{array}{l}53 / 5.9 \\
55 / 5.7 \\
\end{array}$ & 1.58 & 0.00055 \\
\hline 11 & $\begin{array}{l}\text { Cytokeratin-8 } \\
\text { (P11679) }\end{array}$ & See above & $\begin{array}{l}55 / 5.8 \\
55 / 5.7 \\
\end{array}$ & 1.57 & 0.038 \\
\hline 12 & $\begin{array}{c}\text { Carbonic anhydrase } 3 \\
\text { (P16015) }\end{array}$ & See above & $\begin{array}{l}27 / 7.7 \\
30 / 6.9 \\
\end{array}$ & 1.5 & 0.0051 \\
\hline 13 & $\begin{array}{l}\text { Carbonic anhydrase } 3 \\
\text { (P16015) }\end{array}$ & See above & $\begin{array}{l}27 / 7.5 \\
\underline{30 / 6.9} \\
\end{array}$ & 1.5 & 0.017 \\
\hline 14 & $\begin{array}{l}\text { Glutathione S-transferase Mu } 1 \\
\text { (P10649) }\end{array}$ & Catalyses the conjugation of reduced glutathione to a wide number of exogenous and endogenous hydrophobic electrophiles & $\begin{array}{c}24 / 8 \\
26 / 7.7 \\
\end{array}$ & 1.48 & 0.012 \\
\hline
\end{tabular}


Catalyses the synthesis of succinyl-CoA:

Cytokeratin-8

GTP + succinate + CoA $=$ GDP + phosphate + succinyl-CoA

(P11679)

See above

Arginase-1 Catalyses the metabolic degradation og arginine to urea:

(Q61176)

Catalyses the metabolic degradation og ar

ATP synthase $\beta$ subunit

See above

(P56480)

See above

Arginase-1

Glutathione S-transferase Mu 1 See above (P10649)

$34 \quad$ Actin, cytoplasmic 1

Actins are highly conserved proteins that are involved in various types of cell motility and are ubiquitously expressed in all

$42 / 5.2$ (P60710) eukaryotic cells

35 Fructose-bisphosphate aldolase B Catalyses the cleavage of bisphosphorylated fructose into two 3-carbon sugar phosophates:

$$
\text { (Q91Y97) D-fructose 1,6-bisphosphate = glycero phosphate + D-glyceraldehyde 3-phosphate }
$$

36 Carbamoyl-phosphate synthase Involved in the urea cycle of ureotelic animals where the enzyme plays an important role in removing excess ammonia from the (Q8C196) cell

Cytokeratin-18 (P05784)

See above

Metabolises aldehydes concomitant with the production of reducing power: n-aldehyde $+\mathrm{NAD}^{+}+\mathrm{H}_{2} \mathrm{O}=$ an acid $+\mathrm{NADH}$

Aldehyde dehydrogenase (P47738)

Calcium-bi

Regucalcin (Q64374)

Calcium-bi
kidney. Decre

Regucalcin

See above

$34 / 7.5$

40/8.5

$\begin{array}{ll}-1.57 & 0.037\end{array}$ (Q64374) (Q05920) 
${ }^{\mathrm{a}}$ Spots numbered according to Fig. $1 .{ }^{\mathrm{b}}$ Accession number in Swiss-Prot and TrEMBL databases. ${ }^{\mathrm{c}}$ Observed values in DIGE gels. ${ }^{\mathrm{d}}$ Theoretical values. ${ }^{\mathrm{e}}$ Spot density ratio mutant to wild type for up-regulated proteins; the negative value of the ratio wild type to mutated for down-regulated. 
Table 2. 2D-DIGE identified proteins comparing COMT knockout with wild type male mice.

\begin{tabular}{|c|c|c|c|c|c|}
\hline Spot $^{\mathrm{a}}$ & $\begin{array}{l}\text { Protein name } \\
(\text { accession no.) }\end{array}$ & Function & $\mathbf{k D a} / \mathbf{P I}^{\mathrm{c}}$ & Ratio $^{d}$ & p-value \\
\hline \multicolumn{6}{|c|}{ Up-regulated proteins } \\
\hline 1 & $\begin{array}{l}\text { Elongation factor } 2 \\
\text { (P58252) }\end{array}$ & $\begin{array}{l}\text { This protein promotes the GTP-dependent translocation of the nascent protein chain from the A-site to the P-site of the } \\
\text { ribosome }\end{array}$ & $\begin{array}{r}96 / 6.42 \\
96 / 6.4\end{array}$ & +2.5 & 0.0025 \\
\hline 3 & $\begin{array}{l}\text { Albumin serum } \\
\text { (P07724) }\end{array}$ & & $\begin{array}{l}66 / 5.88 \\
\underline{71 / 5.75} \\
\end{array}$ & +2.3 & 0.0047 \\
\hline 6 & $\begin{array}{l}\text { Selenium-binding protein } 2 \mathrm{~b} \\
\text { (Q63836) }\end{array}$ & $\begin{array}{l}\text { Selenium- and acetaminophen-binding protein which may be involved in the sensing of reactive xenobiotics in the cytoplasm. } \\
\text { May be involved in intra-Golgi protein transport }\end{array}$ & $\begin{array}{l}53 / 5.68 \\
\underline{53 / 5.78}\end{array}$ & +2.4 & 0.0029 \\
\hline 8 & $\begin{array}{l}\text { Selenium-binding protein } 2 \mathrm{c} \\
\text { (Q63836) }\end{array}$ & See above & $\begin{array}{l}53 / 5.78 \\
\underline{53 / 5.78}\end{array}$ & +3.3 & 0.001 \\
\hline 15 & $\begin{array}{l}\text { Transferrin } \\
(\text { Q921I1) }\end{array}$ & & $\begin{array}{l}79 / 6.94 \\
79 / 6.9\end{array}$ & +2 & 0.0085 \\
\hline \multicolumn{6}{|c|}{ Down-regulated proteins } \\
\hline 5 & $\begin{array}{l}\text { Selenium-binding protein } 2 \mathrm{a} \\
\text { (Q63836) }\end{array}$ & See above & $\begin{array}{l}53 / 5.59 \\
\underline{53 / 5.78} \\
\end{array}$ & -2.2 & 0.0019 \\
\hline 7 & $\begin{array}{l}\text { Cytokeratin-8 } \\
\text { (P11679) }\end{array}$ & keratin-8 associates with keratin-18 & $\begin{array}{l}55 / 5.7 \\
55 / 5.7\end{array}$ & -1.5 & 0.0022 \\
\hline 9 & $\begin{array}{l}\text { Cytokeratin-18 } \\
\text { (P05784) }\end{array}$ & $\begin{array}{l}\text { When phosphorylated, plays a role in filament reorganization. Involved in the delivery of mutated CFTR to the plasma } \\
\text { membrane. Involved in the uptake of thrombin-antithrombin complexes by hepatic cells (By similarity). Together with KRT8, } \\
\text { is involved in interleukin-6 (IL-6)-mediated barrier protection. }\end{array}$ & $\begin{array}{l}46 / 5.2 \\
\underline{48 / 5.2}\end{array}$ & -2.6 & 0.0045 \\
\hline 12 & $\begin{array}{l}\text { Glutathione S-transferase A4 } \\
\text { (P24472) }\end{array}$ & Conjugation of reduced glutathione to a wide number of exogenous and endogenous hydrophobic electrophiles & $\begin{array}{l}26 / 6.8 \\
26 / 6.8 \\
\end{array}$ & -2.6 & 0.0032 \\
\hline 16 & $\begin{array}{l}\text { Cytokeratin-8 } \\
\text { (P11679) }\end{array}$ & See above & $\begin{array}{l}55 / 5.5 \\
55 / 5.7\end{array}$ & -2 & 0.0053 \\
\hline 17 & $\begin{array}{l}\text { Cytokeratin-8 } \\
\text { (P11679) }\end{array}$ & See above & $\begin{array}{c}55 / 5.59 \\
55 / 5.7\end{array}$ & -2 & 0.007 \\
\hline 18 & $\begin{array}{l}\text { Cytokeratin-18 } \\
\text { (P05784) }\end{array}$ & See above & $\begin{array}{l}48 / 5.2 \\
48 / 5.2 \\
\end{array}$ & -4.6 & 0.006 \\
\hline
\end{tabular}


${ }^{a}$ Spots numbered according to Fig. $1 .{ }^{b}$ Accession number in Swiss-Prot and TrEMBL databases. ${ }^{c}$ Observed values in DIGE gels. ${ }^{d}$ Theoretical values. ${ }^{e}$ Spot density ratio mutant to wild type for up-regulated proteins; the negative value of the ratio wild type to mutated for down-regulated. 


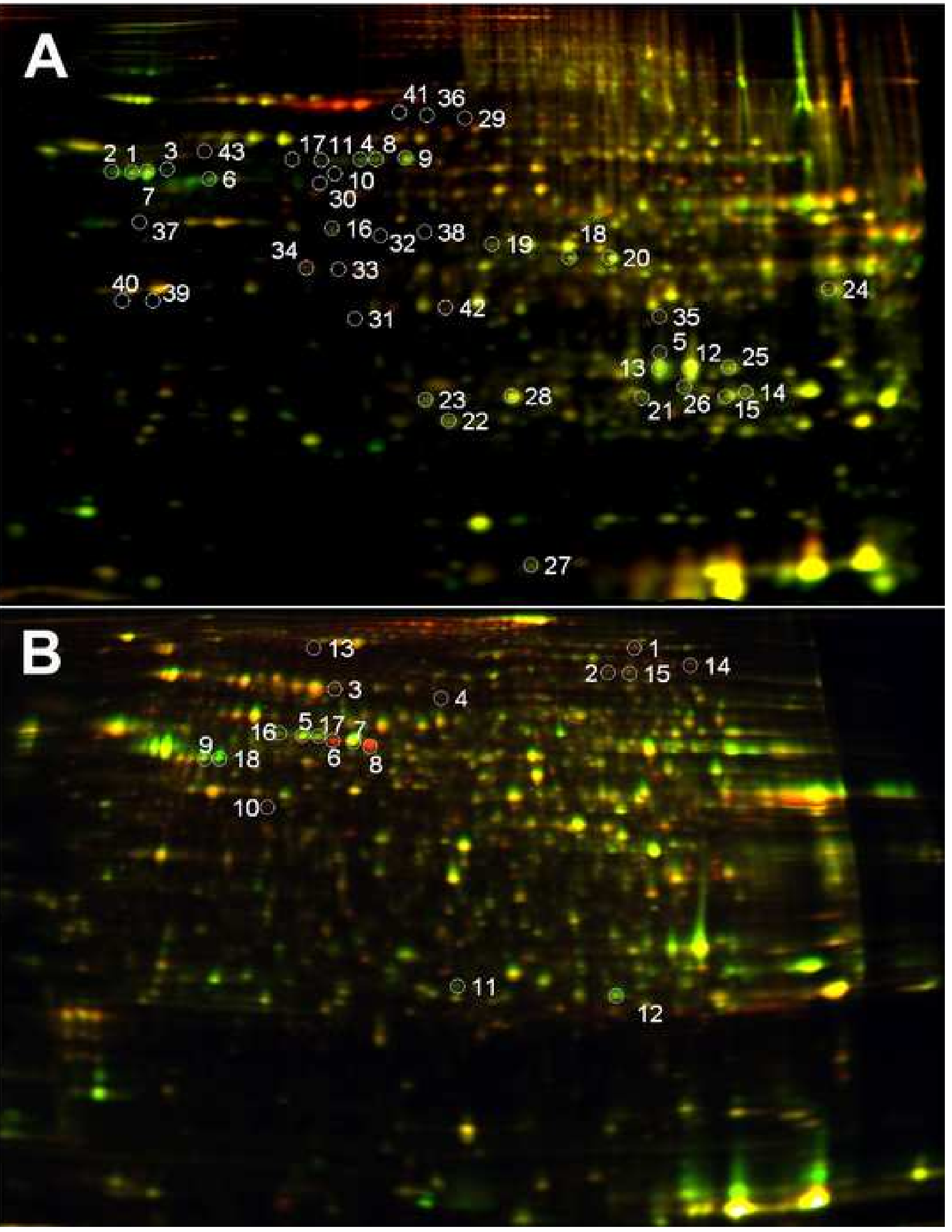


A. GSH : GSSG ratio

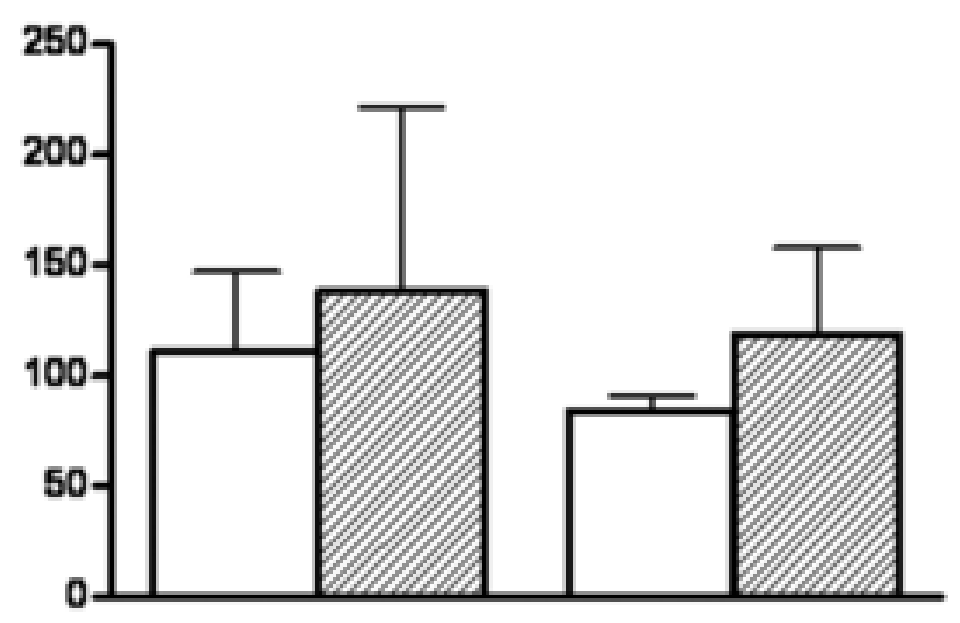

B. Oxidized glutathione

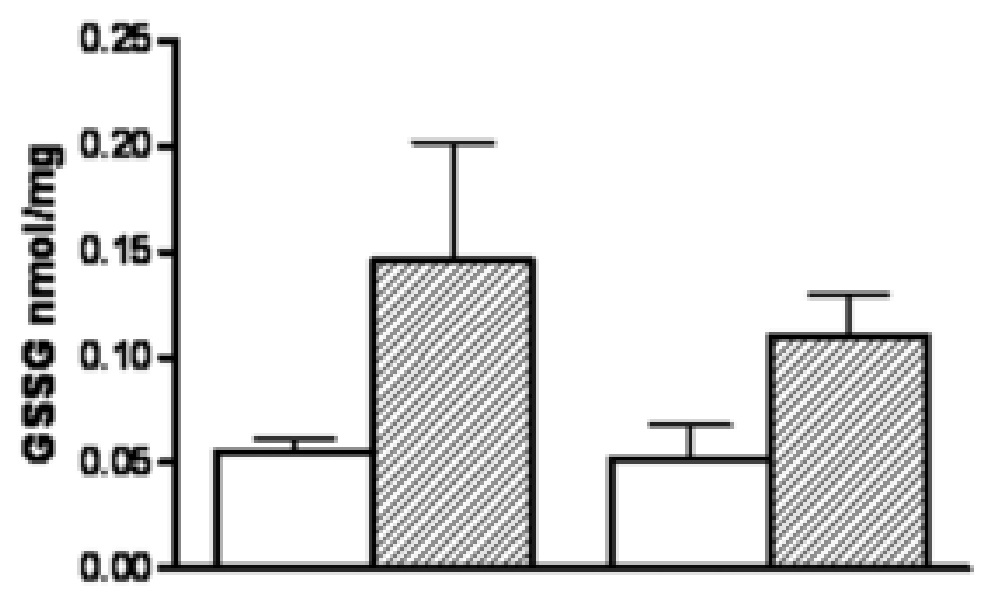

C. Lipid peroxidase

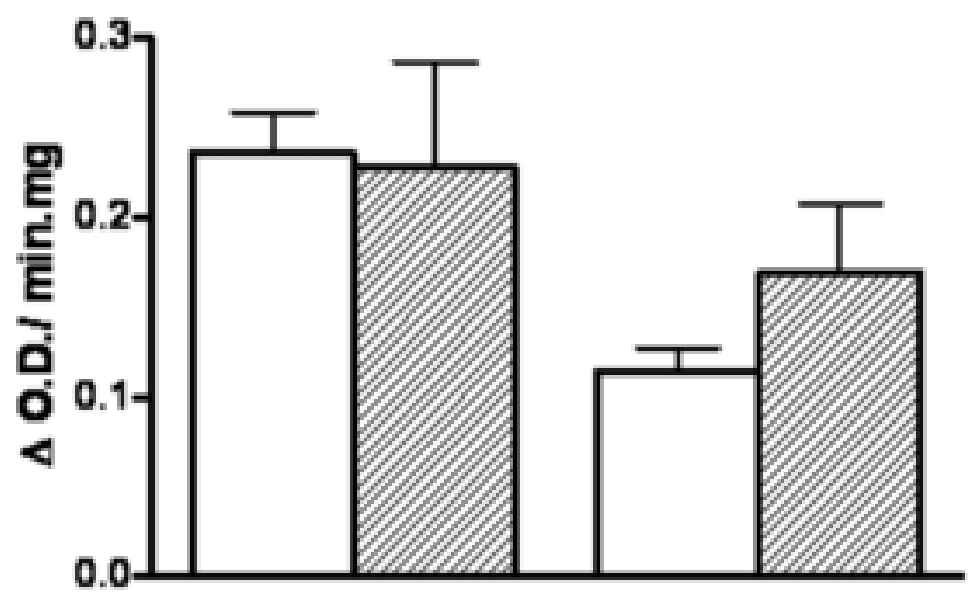


A. Glutathione peroxidase

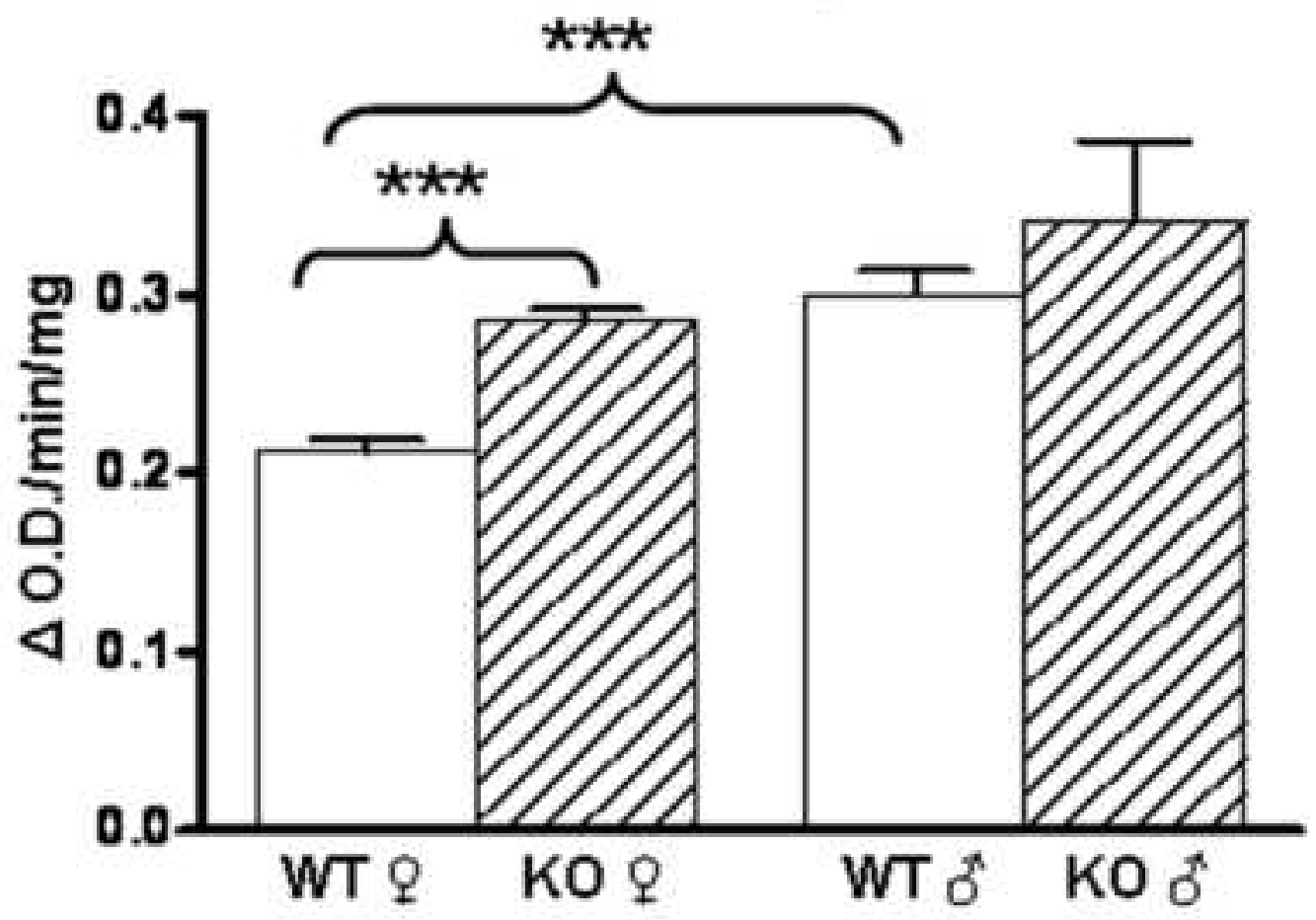

B. Glutathione reductase

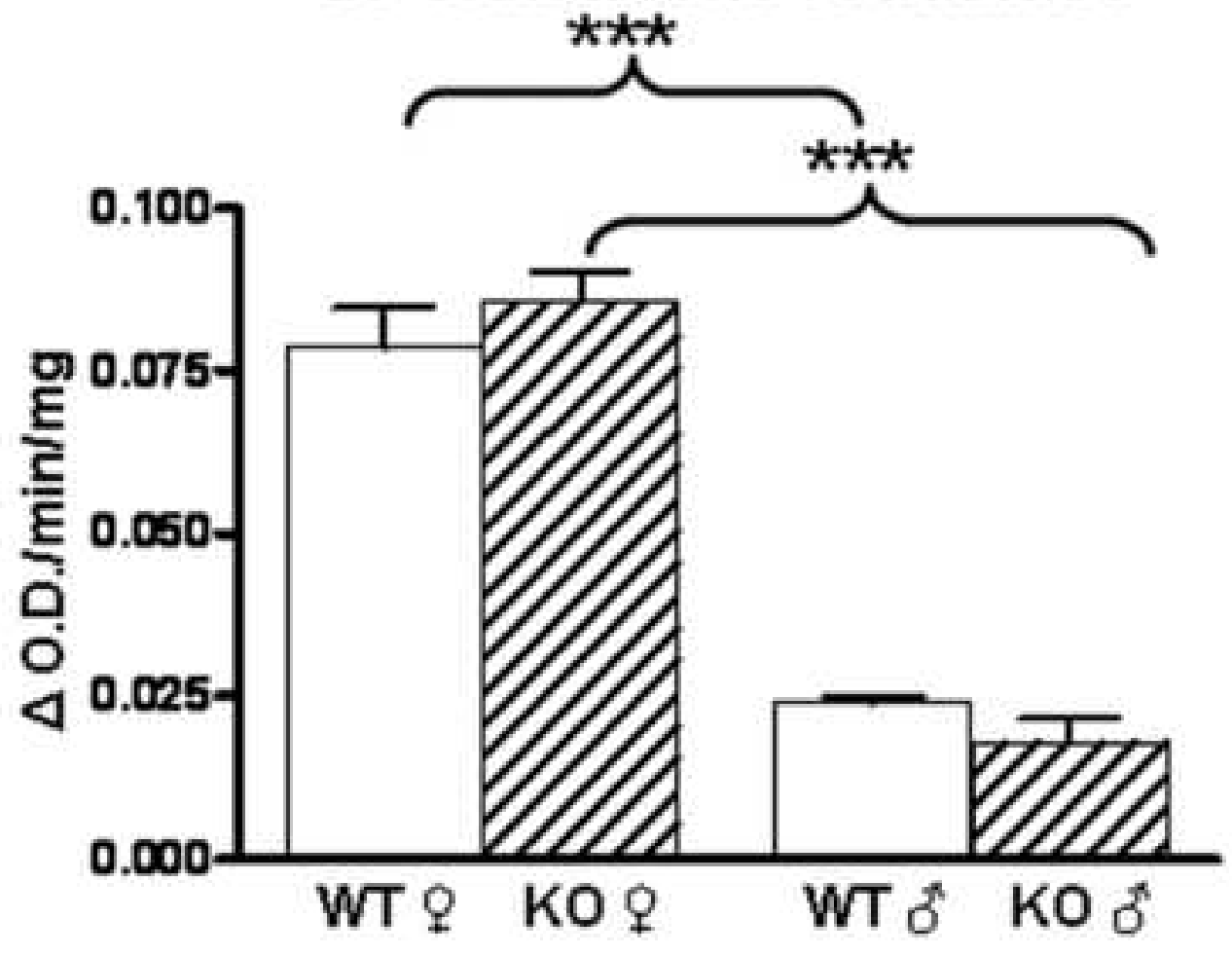




\section{6}

177

000

00

5

6

8

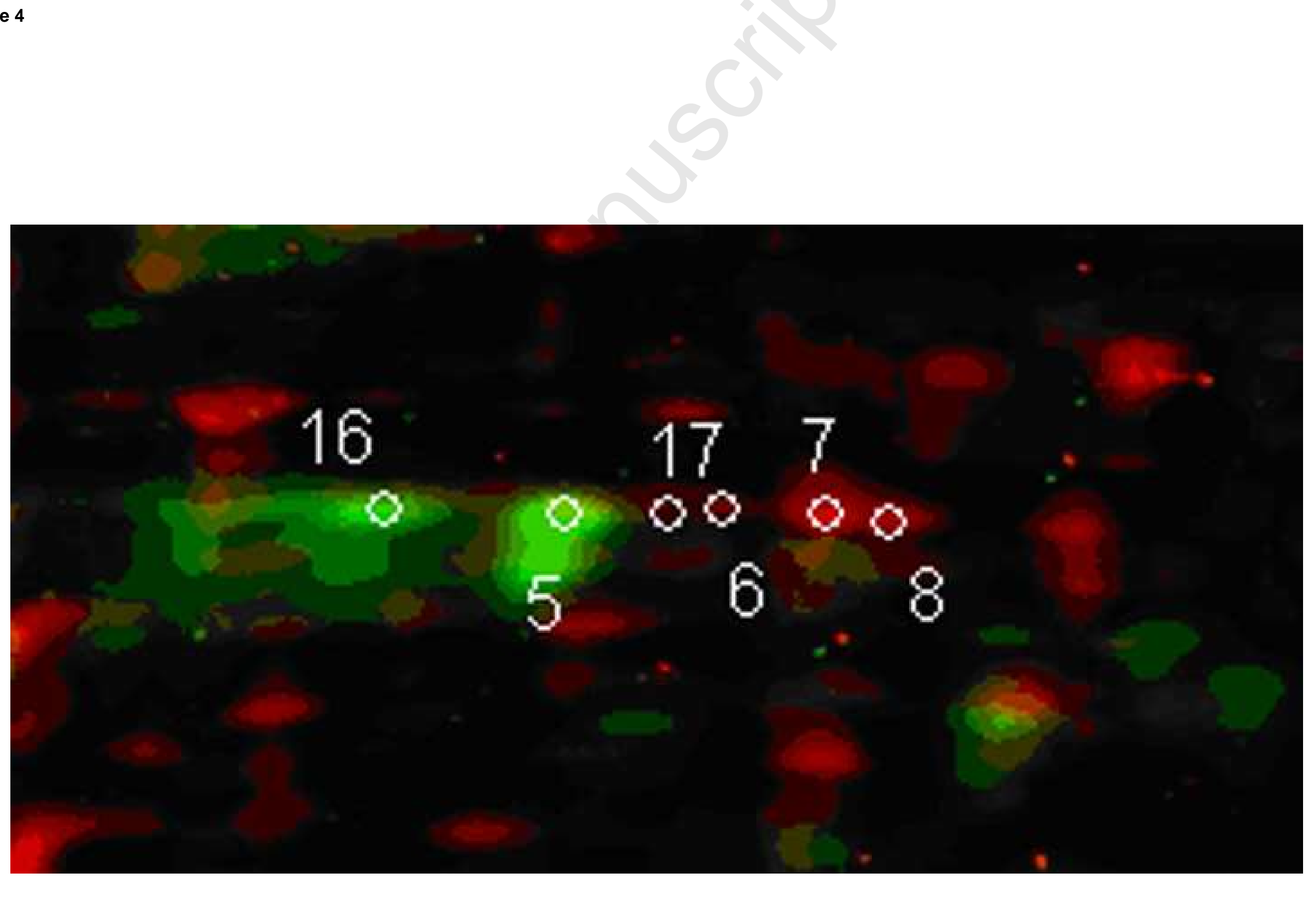

(

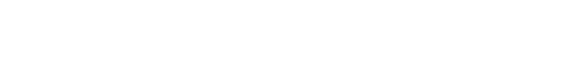

$+2$ 
A. PKC in male liver

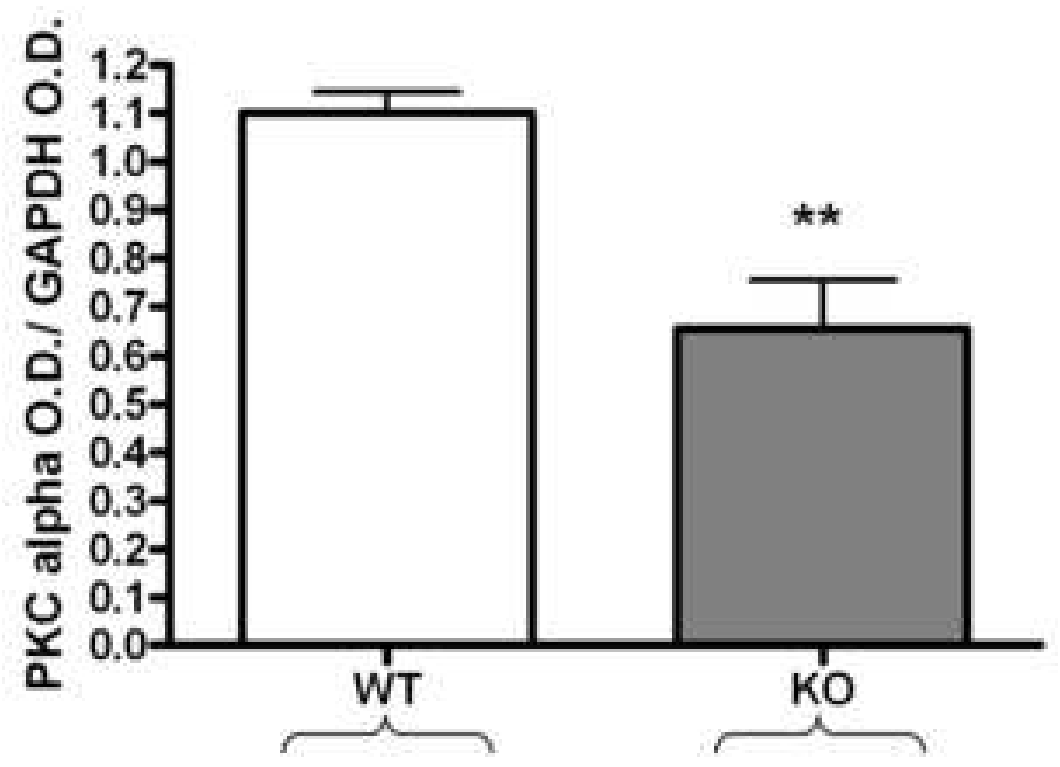

B. $P K C_{\alpha}$ in female liver

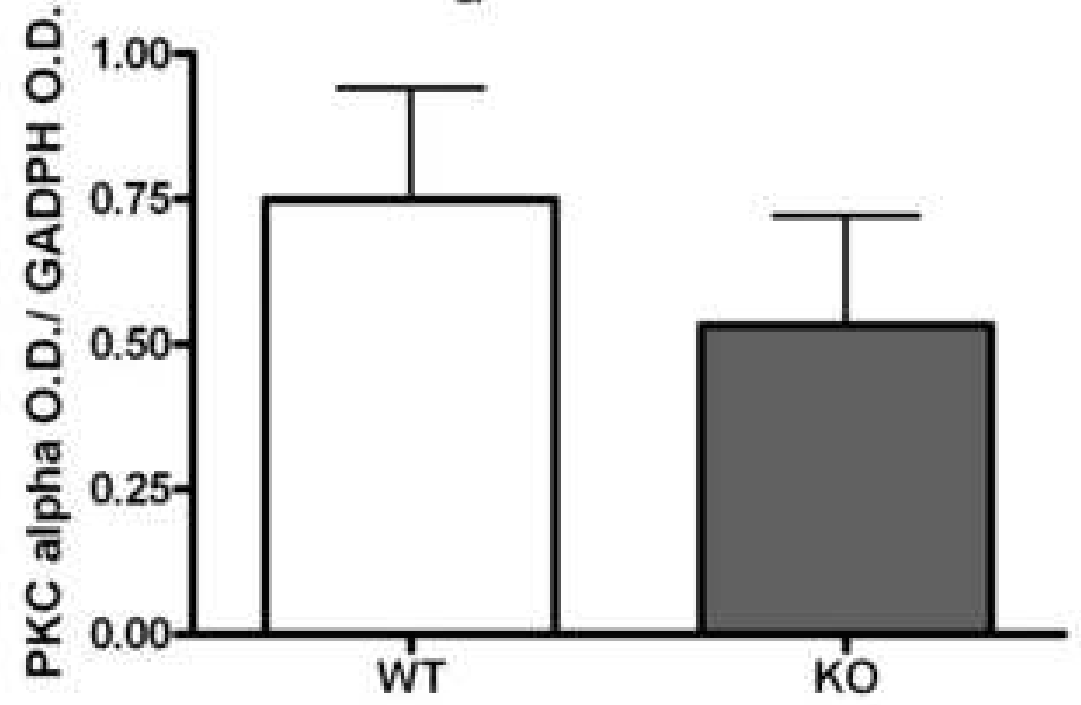


A. PKC in male liver

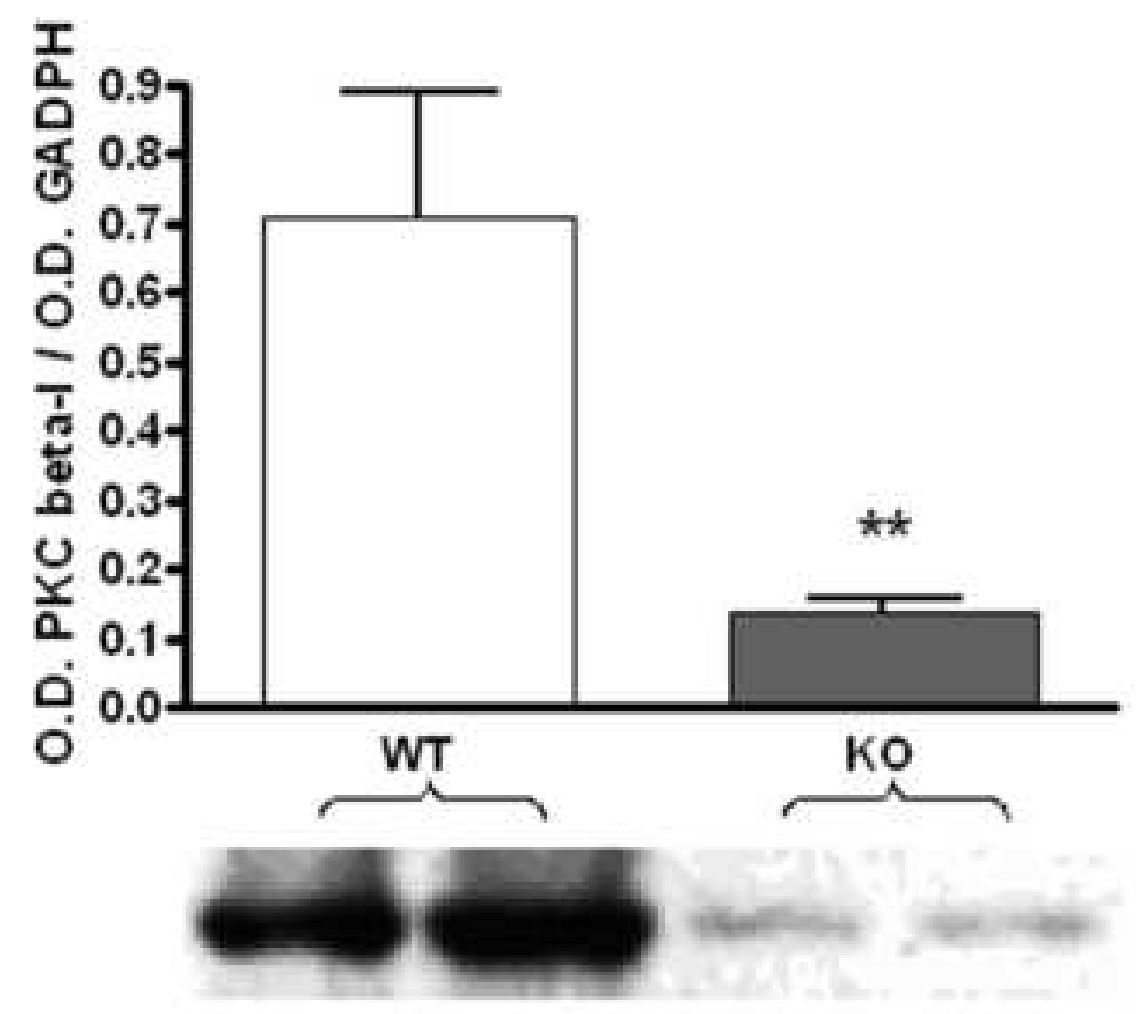

B. PKC in female liver

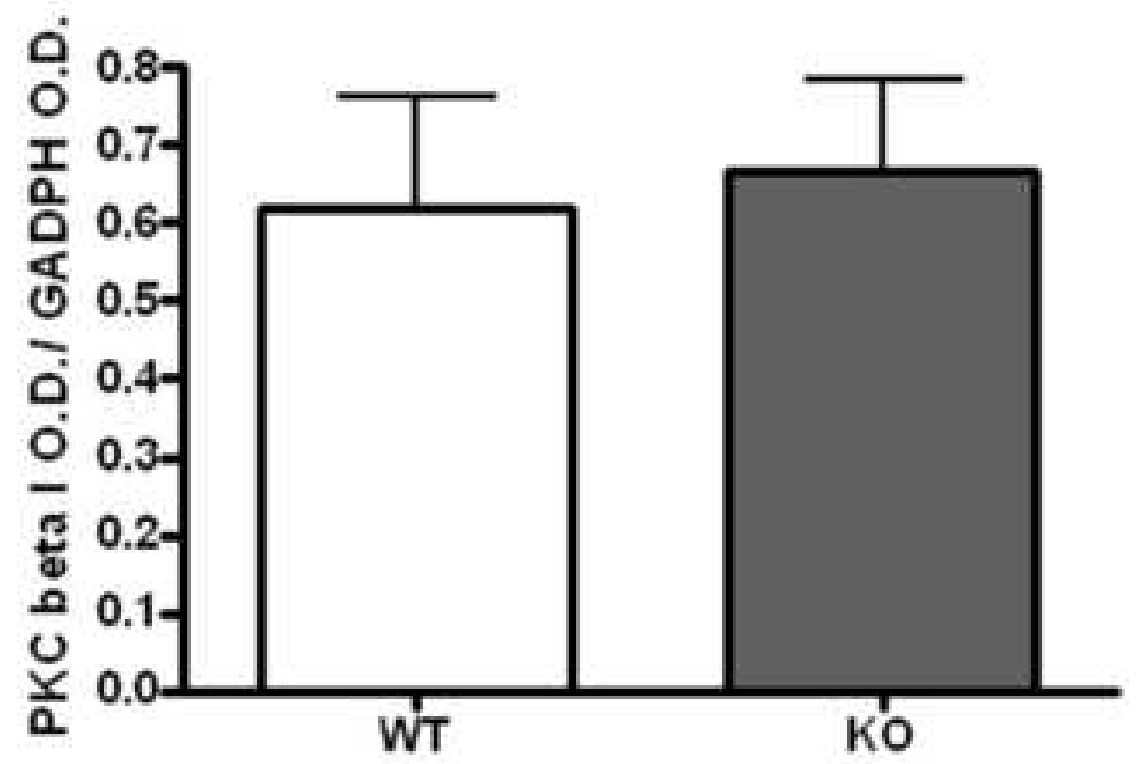




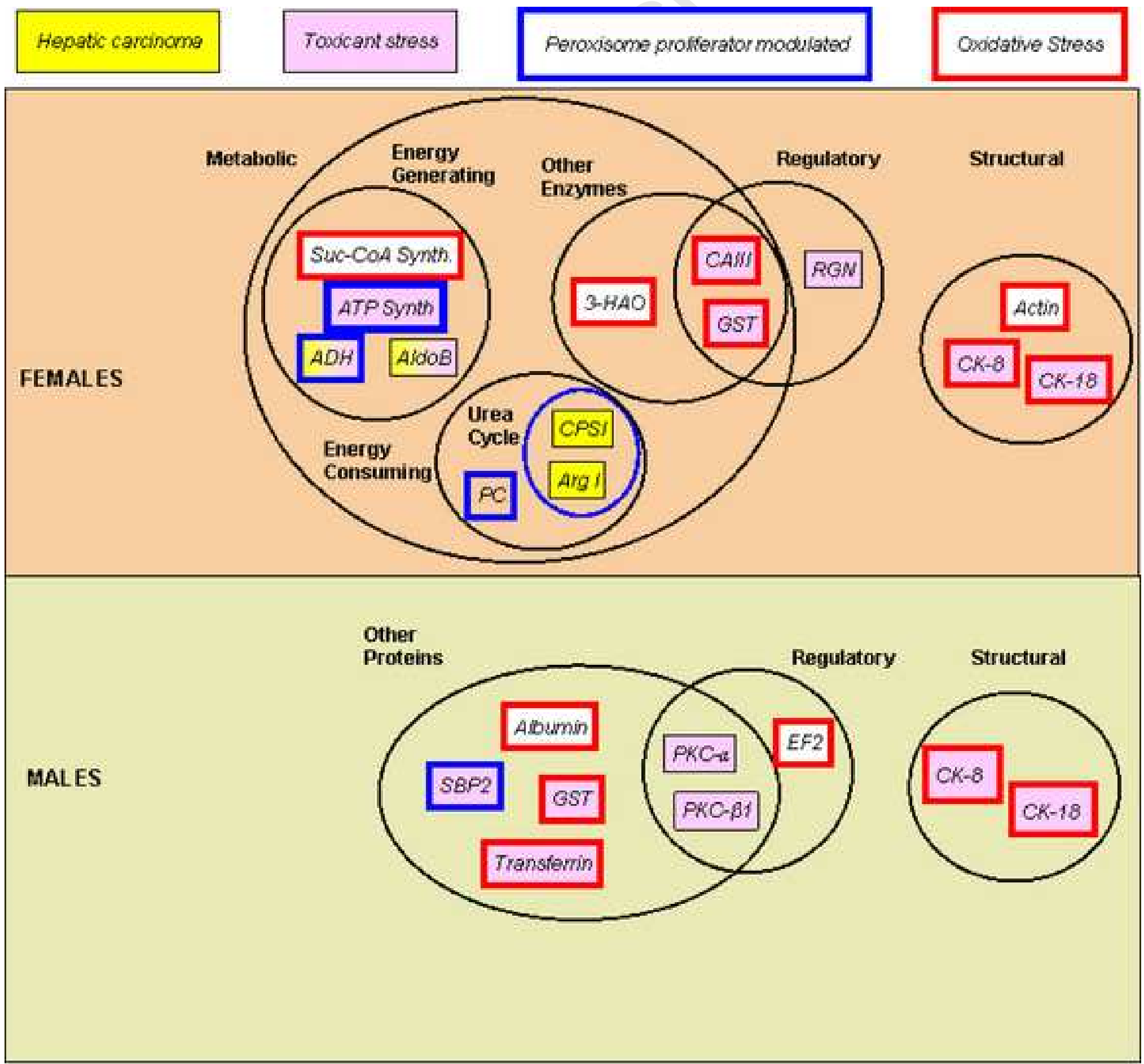

